\title{
Whether Foreigner or Alien: A New Look at the Original Language of the Alien Tort Statute
}

\author{
M. Anderson Berry*
}

I.

INTRODUCTION

In the Supreme Court's only opinion regarding the Alien Tort Statute (ATS), ${ }^{1}$ Sosa v. Alvarez-Machain, the Court unanimously agreed that although the first House of Representatives modified the Senate's draft of what eventually became the Judiciary Act of $1789,{ }^{2}$ "it made hardly any changes to the provisions on aliens, including what became the ATS." 3 The Court did not point out any of these changes, but did comment that, because of the "poverty of drafting history," modern commentators have been forced to concentrate on the text of the ATS itself. ${ }^{4}$ As noted by the Court, commentators have remarked on the in-

* Associate, Jones Day - San Francisco, California. Many thanks to David D. Caron and John C. Yoo, who commented on earlier drafts.

1. 28 U.S.C. $\S 1350$ is generally referred to as the Alien Tort Statute or ATS, but also as the Alien Tort Claims Act or ATCA.

2. This act is formally called An Act to Establish the Judicial Courts of the United States, Ch. 20, 1 Stat. 73 (1789), but will be referred to by its common moniker, the Judiciary Act of 1789; The Senate's Printed Draft referred to is A Bill to Establish the Judicial Courts of the United States ((New-York: Printed by Thomas Greenleaf), (undated) [June 16, 1789]) [hereinafter Senate's Printed Draft], microformed on EARLY AMERICAN IMPRINTS,.No. 45657 (Readex Microprint Corp.) (To avoid confusion with another printed draft, the first line of this version, after the title, is: "Be it enacted by the senate and representatives...."; see also, Oliver Ellsworth, William Paterson \& Caleb Strong, A Bill to Establish the Judicial Courts of the United States (June 12,1789) [hereinafter Senate's Handwritten Draft]).

3. 542 U.S. 692, 696, 718 (2004) (citing Charles Warren, New Light on the History of the Federal Judiciary Act of 1789, 37 HARV. L. REV.. 49 (1923), and William Casto, The Federal Courts' Protective Jurisdiction Over Torts Committed in Violation of the Law of Nations, 18 CONN L. REV. 467, 498 (1986).

4. Sosa, 542 U.S. at 718. The text of the ATS as it appeared in the Judiciary Act of 1789 , Ch. $20, \S 9($ b), 1 Stat. at 76-77, reads: "[The District Courts] shall also have cognizance, concurrent with the courts of the several States, or the circuit courts, as the case may be, of all causes where an alien sues for a tort only in violation of the law of nations or a treaty of the United States" (emphasis 
novative use of the word "tort" ${ }^{5}$ and the mixture of expansive ${ }^{6}$ and restrictive terms. ${ }^{8}$ "But despite considerable scholarly attention," Justice Souter continued, "it is fair to say that a consensus understanding of what Congress intended has proven elusive." 9

Jurists and commentators have also addressed the word "cognizance,"10 and articles considering the ATS in light of Article III speculate about the types of cases the First Federal Congress might have had in mind when it used the phrase "tort only in violation of the law of nations." 11 But until now, the word that puts the "A" in ATS has been overlooked. ${ }^{12}$ No court or commentator has delved into the 1789 meaning of "alien," or into the drafters" understanding of and possible intentions behind that word.

When Justice Souter pointed out in Sosa that the first House made hardly any changes when it modified the Senate's draft of the judicial bill, he could have said that the House made only one change: The bill the Senate submitted for House approval on Monday, July 20,1789, read, in pertinent part, that the District Courts shall have jurisdiction "of all causes where a foreigner sues for a tort only in violation of the law of nations...." 13 The house retained that sen-

added); the ATS as it is currently codified in 28 U.S.C. $\S 1350$ provides: "The district courts shall have original jurisdiction of any civil action by an alien for a tort only, committed in violation of the law of nations or a treaty of the United States."

5. See Joseph Modeste Sweeney, A Tort only in Violation of the Law of Nations, 18 HASTINGS INT'L \& COMP. L. REV. 445 (1995) (arguing that "tort" refers to the law of prize); see, Curtis A. Bradley, The Alien Tort Statute and Article III, 42 VA. J. INT'L L. 587, 621 (2002) (showing, in a letter from Edmund Pendleton to James Madison and Senator Richard Henry Lee, a contemporaneous misunderstanding of the term "tort" as it was used in the Senate's Printed Draft of $A$ Bill to Establish the Judicial Courts of the United States: "What is meant by a Tort? Is it intended to include suits for the Recovery of debts, or on breach of Contracts, as a reference to the laws of Nations \& Federal treaties seems to indicate; or does it only embrace Personal wrongs, according to it's [sic] usual legal meaning, or violations of Personal or Official privilege of foreigners?"). See Thomas H. Lee, The Safe-Conduct Theory of the Alien Tort Statute, 106 CoLuM. L. REv. 830, 837, 870 (2006) (explaining that " $[\mathrm{a}]$ tort, as the word was understood in 1789 , was simply a noncontract injury to person or property.").

6. See, e.g., Casto, supra note 3, at 500 (addressing "all causes").

7. See, e.g., Kenneth C. Randall, Federal Jurisdiction over International Law Claims: Inquiries into the Alien Tort Statute, 18 N.Y.U.J. INT'L L. \& POL. 1, 28-31 (1985) (addressing the restrictive phrase, "for a tort only," limiting suits to torts, as opposed to commercial actions, especially by British plaintiffs).

8. Sosa further acknowledged that the "historical scholarship has also placed the ATS within the competition between federalist and anti-federalist forces over the national role in foreign relations," but only in relation to the possible compromise reflected in the non-exclusiveness of federal jurisdiction surrounding the ATS. Sosa, 542 U.S. at 718; see also Randall, supra note 7, at 22-23.

9. Sosa, 542 U.S. at 718-19.

10. Casto, supra note 3 , at $479, \mathrm{n} .61$ (finding that cognizance is synonymous with jurisdiction and "refer[s] to a court's power to try a case.").

11. Bradley, supra note 5, at 590.

12. See, Lee, supra note 5 , at 849 .

13. A Bill to Establish the Judicial Courts of the United States, 4, 11. 6, 7 ((New-York: Printed by Thomas Greenleaf.), (undated [July 23, 1789])) [hereinafter House's Printed Draft], microformed 
tence, except for changing "a foreigner" to "an alien." The word "alien" did not appear in this part of the bill until the House put it there. ${ }^{14}$ This was not mere happenstance.

It is clear that the House changed "foreigner" to "alien" sometime after it printed the House's Printed Draft of the judicial bill on July 23, 1789, and before the bill was enacted that September. ${ }^{15}$ What is not clear is why. The Senate and House Journals, the voluminous Documentary Histories of the Supreme Court and the First Federal Congress, Maclay's Journals, countless private correspondences - neither these sources nor others address the change from "foreigner" to "alien." 16

When the House passed the judicial bill by voice vote on September 17, 1789 , there were more than fifty amendments headed back to the Senate along with it. ${ }^{17}$ Some Representatives viewed the proposed changes as "small alterations," 18 "none of [which] materially alter the plan," 19 but the Representative from Virginia, James Madison, believed that "the amendments made by the

on EARLY AMERICAN IMPRINTS, NO. 45683 (Readex Microprint Corp.) (To avoid confusion with the Senate's Printed Draft, the first line after the title of this version is: "Be it enacted by the Senate and House of Representatives....") (This bill is Evans 21, 511, although incorrectly dated as 1788 . WILFRED J. RITZ, REWRITING THE HISTORY 187 (1989); also incorrectly dated as 1791 by the Library of Congress website: available at http://memory.loc.gov/ammem/rbpehtml/rbpebibTitles 13.html).

14. On the page the Sosa Court cited from Casto, supra note 3, Casto wrote: "The word 'alien' was substituted for the word 'foreigner"' by the House. Casto, supra note 3, at 498 . However, Casto does not elaborate on this seemingly simple alteration. In fact, after an exhaustive search, no commentators before or since Casto have addressed the change with any substance: See, e.g. Steven Fogelson, The Nuremberg Legacy: An Unfilled Promise, 63 S. CAL. L. REV. 833, 890-91 (1990) (mentioning but not addressing that the precise language of the resolution (i.e., "foreigner") was subsequently revised); Dennis J. Mahoney, A Historical Note on Hodgson v. Bowerbank, 49 U. CHI. L. REV. 725, 731-32 (1982) (neglecting to acknowledge the use of "foreigner" in various sections of the Senate's Printed Draft and/or the Senate's Handwritten Draft of $A$ Bill to Establish the Judicial Courts of the United States, where it would have 1) further served to prove Mahoney's point regarding alienage jurisdiction, and 2) corrected his assertion that Ellsworth was personally responsible for the confusing language in section 11 of the Judiciary Act of 1789).

15. Compare the House's Printed Draft, p. 4, line 6 from bottom, with the Judiciary Act of 1789 , Ch. $20, \S 9,2^{\text {nd }}$ sentence.

16. See, 11 The Documentary History Of The First Federal Congress Of THe United States OF AMERICA, March 4, 1789-MarCh 3, 1791, Debates IN THE House OF REPRESENTATIVES, FIRST SESSION, JUNE-SEPTEMBER, 1789 (1992) [hereinafter 11 DHFFC] (John P. Kaminski \& Gaspar Saladino, et al, eds., 1993); see, 4 THE DOCUMENTARY HISTORY OF THE SUPREME COURT OF THE UNITED STATES, 1789-1800 (1992) [hereinafter 4 DHSC]; THE JOURNAL OF William Maclay, United States Senator From PENNSYlvania, 1789-1791 (Edgar S. Maclay ed.) (1890) [hereinafter MACLAY'S JOURNALS]; See, 1 ANNALS Of CONG. (Joseph Gales ed., 1834).

17. 1 Journal of the House of Representatives of the United States 115-16 (1789) [hereinafter I House Journal].

18. Letter from Roger Sherman to Samuel Huntington, (September 17, 1789) in Wm. Griswold Lane Collection, Yale University, New Haven, Conn.

19. Letter from Paine Wingate to John Langdon, (September 17, 1789) in CHARLES EdGAR LEWIS WINGATE, 2 The Life AND LeTters of PAINE WiNGaTe 334 (1930). 
house had $[\ldots]$ removed the principal objections to [the bill]." 20 Madison did not elaborate on these principal objections or the consequent changes, but at least one significant change warranted his comment. Was substituting "alien" for "foreigner" the change that allowed the bill to pass-at least in Madison's eyes?

Some may argue that considering the interchangeability of the words "alien" and "foreigner" in a modern context makes it seem unlikely that this particular alteration changed anything. Today, in common parlance, we use "alien" to describe a person residing in another country (or even on another planet!), and we use "foreigner" when we speak of a person born outside the United States who resides here, and vice versa. One definition of the noun "alien" in the current edition of the Oxford English Dictionary ("OED") is: "A person belonging to another family, race, or nation; a stranger, a foreigner." 21 The $O E D$ contains a similarly interchangeable definition for "foreigner": "A person born in a foreign country; one from abroad or of another nation; an alien." The American Heritage Dictionary of the English Language, among countless others, contain similar definitions, but do not usually go as far as the $O E D$ by specifically using one term to define the other. ${ }^{22}$

The legal definitions paint a much different picture. A prime example is Black's Law Dictionary, which is much more specific than the general lexicons. The eighth and most current edition primarily defines the noun "alien" as a "person who resides within the borders of a country but is not a citizen or subject of that country." 23 Residency is key. ${ }^{24}$

20. The Daily Advertiser, 18 September 1789 , in 11 DHFFC at 1479 , supra note 16 . Later, at the age of 85 , Madison contradicted this statement when he claimed that the judicial bill was "not materially changed in its passage into a law." Letter from Madison to Joseph Wood, (February 27, 1836) in Philip R. Fendall, 4 Letters and Other Writings of James Madison 427-28 (1865). Charles Warren did not cite the first Madison quote from the The Daily Advertiser, but still concluded that Madison's 1836 comment was incorrect in light of the information Warren discovered; that is, the Senate's Handwritten Draft of the judicial bill. See, Warren, supra note 3, at 51 (giving the name of the letter recipient as Joseph "Ward").

21. Another $O E D$ definition is: "One who is a subject of another country than that in which he resides. A resident foreign in origin and not naturalized, whose allegiance is thus due to a foreign state." OXFORD ENGLISH DICTIONARY, available at http://www.oed.com.

22. The American Heritage Dictionary OF The English Language (4th ed. 2004) (defining Alien (n): "1) An unnaturalized foreign resident of a country. Also called noncitizen; 2) A person from another and very different family, people, or place"; and defining Foreigner $(n)$ : " 1$)$ One who is from a foreign country or place; 2 ) One who is from outside a particular group or community; an outsider.").

23. BLACK'S LAW DictionaRy 79 (Bryan A. Garner ed., 8th ed. 2004). An earlier BLACK'S LAW DiCTIONARY (2d ed. 1910) does not use "alien" to define "foreigner" either: Foreigner: "A person who is not a citizen or subject of the state or country in which mention is made, or any one owing allegiance to a foreign state or sovereign"; and specifies that: "In old English law, this term, when used with reference to a particular city, designated any person who was not an inhabitant of that city." Id. at S11. However, this edition of BLACK'S does use "foreigner" to define "alien," but qualifies it: Alien: "a foreigner; one born abroad; a person resident in one country, but owing allegiance to another," indicating that "alien" is a subset of "foreigner." Id. at 57. 
Unlike the $O E D$, Black's does not use "foreigner" to define "alien," and does not use "alien" to define "foreigner": It supplies only two terse definitions for "foreigner." The first is "[a] person not an inhabitant of a particular city under discussion"; the second: "[a] citizen of another country." 25

The current legal definitions are clearer on this point than the general definitions: A "foreigner" is a person born extraterritorially, usually residing outside the country in which mention is made; an "alien" is a "foreigner" not residing in the country of his birth. ${ }^{26}$ Even the Congressional ${ }^{27}$ and most general definitions, although muddled, make this residential differentiation.

This modern confusion was not foreign (or alien) in the late eighteenth century. In fact, some might argue that the House's change from "foreigner" to "alien" was simply stylistic. ${ }^{28}$ However, when the Judiciary Act of 1789 was written, "alien" and "foreigner" had distinct legal meanings, very similar to the legal definitions today. Considering Article III of the Constitution and the related provisions in the Judiciary Act of 1789 , along with the late eighteenth century legal, international, and general uses and definitions of "alien" and "foreigner"-in conjunction with relevant changes that occurred from the Senate's Handwritten Draft of the judicial bill through subsequent codifications of relevant sections of the Judiciary Act of 1789-it is fair to say that an understanding of what Congress intended by the deceptively simple change from "foreigner" to "alien" was a narrowing of the ATS; making it available to "aliens" but not to "foreigners." 29 In other words, making it available only to residents of the

24. In 8 U.S.C.S. $\$ 1101(a)(3)$ Congress defined "alien" as "any person not a citizen or national of the United States." However, this was only to be considered "[a]s used in this Act," and is consequently muddled when "immigrant" is later defined as "every alien." 8 U.S.C.S. §1101(a)(15). If every alien is an immigrant under this act, foreign-born individuals residing extraterritorially, who have no intention of emigrating from their respective countries, would not be considered "aliens."

25. Other legal dictionaries, including THE OXFORD DictronaRY OF LAW and THE LAW DictionaRY, do not define "foreigner," but do define "alien" as "a person of foreign birth who is not a citizen," and as a "person who, under the law of a particular state, is not a citizen of that state." THE LAW DICTIONARY (online at Lexis) (2002) (defining "foreign" as "something which belongs to another country."); THE OXFORD DICTIONARY OF LAW $23\left(5^{\text {th }}\right.$ ed. 2002). These definitions are as unclear as BLACK'S latter "alien" definition, but in context they similarly indicate that residency is paramount in differentiating between an "alien" and a "foreigner."

26. THE OXFORD DICTIONARY OF LAW also defines "Alien" as "usually classified as resident aliens (domiciled in the host country) or transient aliens (temporarily in the host country on business, study, etc.). They are normally subject to certain civil disabilities, such as being ineligible to vote." Id.

27. See supra note 24 (defining "alien" in 8 U.S.C.S. $\$ 1101$ (a)(3) and (15)), and infra note 443 and accompanying text (defining "alien" in 28 U.S.C. $\$ 1332$ ).

28. The terms were not simply synonymous; as shown below, "alien" is a subset of "foreigner," and therefore "foreigner" can be used for "alien," but "alien" cannot be substituted for "foreigner" in certain instances (e.g., for an individual residing extraterritorially).

29. Furthermore, subsequent Congressional changes to relevant sections of the Judiciary Act of 1789 enforce this proposition. See, infra Part VI. 


\section{United States. ${ }^{30}$}

To understand the significance of the change from "foreigner" to "alien," the original understanding of both terms from the point of view of the relevant drafters (including the Senators and Representatives who discussed and passed the bill, among others) must be understood. ${ }^{31}$ As a supplement to the Constitution under the Madisonian Compromise, ${ }^{32}$ the meaning of the Judiciary Act of 1789 , like the Constitution, should not change from the meaning it held for its drafters. ${ }^{33}$ The main source of this understanding comes from the legal and general dictionaries and treatises that defined the words in and before 1789 . This includes works available to the drafters, from Justinian's Institutes to Blackstone's Commentaries, and even collateral sources that do not define the terms, but use them in the definition of other terms. ${ }^{34}$

Dictionaries and treatises are much more informative in deciphering the original understanding than defining the terms from the ways in which they were used in available writings, partly because of the lack of sources and general misunderstandings, but mainly because an "alien" was considered a "foreigner" but not all "foreigners" were considered "aliens," and therefore in certain instances "foreigner" was properly used when referring to a foreign-born individual residing in the United States. Informative sources include Acts passed by the First Federal Congress, Federal and State Court opinions, the Constitutions of the several states, the Federal Convention of 1787 and the ratification debates, The Federalist and Anti-Federalist Papers, personal correspondences, and private works, for example, Thomas Jefferson's Notes on the State of Virginia, Maclay's Journal and Elliot's Debates.

Part II of this Article shows a distinction between the terms "alien" and "foreigner" in 1789, acknowledged by relevant legislators and writers. Part III details the relevant changes made from the initial handwritten draft of the judiciary bill to the final product: the Judiciary Act of 1789. Part IV differentiates and painstakingly defines "alien" and "foreigner" and related words using legal, international, and general lexicons available to the First Federal Congress. Part V details an understanding of the terms as used in relevant historical writings, and introduces the possible reason for the change from "foreigner" to "alien." That is, respected and relevant late eighteenth century writers and debaters exclusively used the noun "foreigner" when discussing most constitutional topics that affected both "aliens" and "foreigners." 35 This wide, exclusive use shows that

30. In his dissent in Cherokee Nation v. Georgia, Supreme Court Justice Johnson wrote: "We call an alien a foreigner, because he is not of the country in which we reside." 30 U.S. 1, 56 (1831).

31. See John C. Yoo, The Continuation of Politics by Other Means: The Original Understanding of War Powers, 84 CAL. L. REV. 167, 172 (1996).

32. See infra note 57-58 and accompanying text.

33. See id.

34. See Lee, supra note 5, at 839.

35. Robert Yates noted on June 13,1787, that "[Edmund] Randolph observed the difficulty in 
the relevant writers and debaters thought about these subjects in terms of "foreigners," not "aliens," and therefore it makes sense that Oliver Ellsworth would later draft the relevant sections of the original judiciary bill using "forreigner." Part VI concludes that the Senate's original intent of the Judiciary Act of 1789 was to make the ATS available to all non-citizens born outside the United States- "foreigners"-but that Congress as a whole intentionally narrowed the scope in the Judiciary Act of 1789 and later codifications, making the ATS only available to plaintiffs who are foreign-born residents of the several States (that is, "aliens"). In fact, when Congress enacted the Torture Victim Protection Act of 1991 ("TVPA"), ${ }^{36}$ it intended that the TVPA-like the ATS—only protect "aliens" "living in this country." 37

II.

THere WaS A Difference BETWEen A "FOREIGNER" AND AN “ALIEN" IN 1789

In the House on Monday, August 31, 1789, Representative John Vining of Delaware debated section 3 of the House's Printed Draft of the judicial bill, which deals with the establishment of Federal District Courts, with, among others, Representatives Samuel Livermore of New Hampshire and Michael J. Stone of Maryland. ${ }^{38}$ Livermore believed that "[t]his new fangled system will eventually swallow up the State Courts," because, among other things, of the speed plaintiffs would collect from defendants compared to the snail's pace at which State courts operated. ${ }^{39}$ He thought it best to completely dispose of District Courts, and his point of view was published in various newspapers. ${ }^{40}$ Stone supported this position of his fellow anti-federalist, pointing out "the advantages

establishing the powers of the judiciary-the object however at present is to establish this principle to wit, the security of foreigners where treaties are in their favor, and to preserve the harmony of States and that of the citizens thereof. This being once established, it will be the business of a subcommittee to detail it; and therefore moved to obliterate such parts of the resolve so as only to establish the principle, to wit, that the jurisdiction of the national judiciary shall extend to all cases of national revenue, impeachment of national officers, and questions which involve the national peace or harmony." Notes of the Secret Debates of the Federal Convention of 1787, Taken by the Late Hon Robert Yates, Chief Justice of the State of New York, and One of the Delegates from That State to the Said Convention, at June 13,1787, available at http://www.yale.edu/lawweb/avalon/const/yates.htm (last visited March 3, 2009) (emphases added). Although "torts" are not mentioned here, the connection between "foreigners," "treaties" and "national peace" could relate to the ATS.

36. 28 U.S.C. $\$ 1350$, n.2.

37. Hearing and Markup re: 100 HR 1417, Committee on Foreign Affairs, March 23, Apr. 20, and June 7, 1988 at 1 (emphasis added).

38. 1 ANNALS OF CONG. 851-57; Livermore led the attack on the bill when it came to the House.

39. Id at 852 .

40. Id. 
that foreigners would have over the citizens." ${ }^{41}$

In defense, Representative Vining argued that the planned federal judiciary, the District Courts in particular, were "essential to the fair and impartial administration of the laws of the United States": "I wish to see justice so equally distributed" he said, addressing the whole House on the last day of August 1789, "as that every citizen of the United States should be fairly dealt by, and so impartially administered, that every subject or citizen of the world, whether foreigner or alien, friend or foe, should be alike satisfied." 42

By saying "foreigner or alien" in the House during the judicial bill debate, Vining conveyed a difference between the terms and what they represent. He apparently believed his fellow Representatives would comprehend the difference, because he did not explain it. By contrasting "friend" with "foe" immediately thereafter, Vining further indicated an understood, drastic distinction, and by including "every subject or citizen of the world," also an understandable contrast to these legislators, he referenced the relevant Constitutional grant of jurisdiction over "foreign [...] Citizens or Subjects." "43

No one challenged Vining's "foreigner or alien" distinction during those lengthy judicial bill discussions in late August and early September 1789.44 Other Representatives elaborated on aspects of Vining's debate, and when a vote was taken on this subject it went in Vining's favor eleven to thirty-one. ${ }^{45}$

Two days before Vining's remark, Representative Stone made the same distinction. While asking whether federal jurisdiction over alienage claims ought to be exclusive, Stone said: "If it is the [Constitutional] right of an alien or foreigner to sue or be sued only in the courts of the United States, then they have a right to that jurisdiction complete." ${ }^{46}$ Like Vining's remark, Stone's did not provoke a response one way or the other, which again indicates that his fellow Representatives understood the "alien or foreigner" differentiation.

Moreover, in The Federalist No. 22, written less than two years earlier, Alexander Hamilton also used "alien" and "foreigner" in a way that indicated an understood difference. ${ }^{47}$ While discussing the importance of the national government's proposed power to regulate commerce so as to secure uniformity in the States' commercial dealings with one another, Hamilton ended with this: "[W]e may reasonably expect, from the gradual conflicts of State regulations,

41. Id. at 854 (quoting Stone: "A citizen can now get his money in three years, with an interest of 5 pr. cent. But in these courts, foreigners can get their debts in one year, with an interest of 7 or 8 pr. cent. From the foregoing I conceive, that this system cannot be agreeable to the people.")

42. Id.

43. U.S. CONST. art. III, § 2, cl. 1.

44. See, generally, 1 ANNALS OF CONG., supra note 15, at 851-66.

45. Id. at 866 .

46. Id. at 841 (emphases added).

47. THE FEDERALIST No. 22 (Alexander Hamilton), available at http://avalon.law.yale .edu/18th_century/fed22.asp (last visited March 3, 2009). 
that the citizens of each [State] would at length come to be considered and treated by the others in no better light than that of foreigners and aliens." 48

There was a difference between "foreigner" and "alien," and men familiar with Publius's recent and widely read work, and present during Stone's and Vining's remarks in late August 1789 - the very men responsible for the change from "foreigner" to "alien" in the judicial bill-understood what that difference meant. These same men also knew the importance of the judicial bill, especially Madison, and therefore the importance of each and every word the Judiciary Act of 1789 would contain. ${ }^{49}$

III.

RELEVANT Changes MADE FROM THE INITIAL HANDWRITTEN DRAFT OF THE JUDICIARY BILL TO THE JUDICIARY ACT OF 1789

Before further detailing the textual definitions and uses of "alien" and "foreigner" circa 1789 , it is necessary to first track relevant changes to the judicial bill from its origin in Article III of the Constitution, to the Senate committee that debated and created the judicial bill beginning in April 1789, through the Senate's changes from the Senate's Handwritten Draft to the Senate's Printed Draft of June 1789 , and then to the House and its debates and alterations of the House's Printed Draft of July 1789 that eventually became-after a lightning round in the Senate that ended on September 17, 1789--the Judiciary Act of 1789.

\section{A. The Constitution}

The Constitution does not mention anything directly relating to the ATS, and does not contain the words "alien" or "foreigner." The only relevant instances where the Constitution generally refers to foreigners or aliens are:

1) Article I $\S 8$ : "The Congress shall have Power . . . To establish an uniform Rule of Naturalization . . . To define and punish Piracies and Felonies committed on the high Seas, and Offenses against the Law of Nations." 50

2) Article I § 9: "The Migration or Importation of such Persons as any of the States now existing shall think proper to admit, shall not be prohibited by the Congress prior to the Year [1808]." 51

48. Id.

49. Madison was not only instrumental in devising and ratifying the Constitution. The Madisonian Compromise and its consequential judicial bill was arguably his idea, and, as stated, he was present and active in the House, as Virginia's Representative and in reworking and approving what became the Judiciary Act of 1789 . See, infra notes 57-58 and accompanying text.

50. U.S. Const. art. I, $\$ 8$, cls. $4,10$.

51. Id. at art. I $\S 9, \mathrm{cl} .1$ (neglecting to define "such Persons.") 
3) Article II $\S 3$ : The President "shall receive Ambassadors and other public Ministers."

4) Article III $\S 2$ : "In all Cases affecting Ambassadors, other public Ministers and Consuls, and those in which a State shall be Party, the supreme Court shall have original Jurisdiction." 52

5) Article III $\S 2$ : "The judicial Power shall extend . . . to all Cases affecting Ambassadors, other public Ministers and Consuls; to all Cases of admiralty and maritime Jurisdiction." 53

6) Article III § 2: "The judicial Power shall extend to ... Controversies ... between a State, or the Citizens thereof, and foreign States, Citizens or Subjects." 54

Article III, section 2 granted jurisdiction to the federal judiciary, in pertinent part, in cases or controversies between: 1) Foreign Citizens or Subjects v. States; ${ }^{55}$ 2) Foreign Citizens or Subjects v. State Citizens; and 3) The United States v. Foreign Citizens or Subjects. ${ }^{56}$ As was only generally understood at the time-but not firmly established until the turn of the century-there was no grant of jurisdiction regarding suits involving Foreign Citizens or Subjects v. Foreign Citizens or Subjects. ${ }^{57}$ This was later prohibited by the express grant of Foreign Citizens or Subjects v. U.S. Citizens and/or States. ${ }^{58}$ Therefore, in

52. Id. at art. III $\S 2$, cl. 2.

53. Id. at art. III $\S 2, \mathrm{cl} .1$ (covering certain "foreigners"; that is, ambassadors et al.)

54. Id ; The $11^{\text {th }}$ Amendment will become relevant later; it was not proposed until March 4, 1794, and ratified February 7, 1795: "The Judicial power of the United States shall not be construed to extend to any suit in law or equity, commenced or prosecuted against one of the United States by Citizens of another State, or by Citizens or Subjects of any Foreign State." The word, "inhabitant" was used five times in the Constitution. U.S. CONST. art I § 2, cl. 2; art I § 3, cl. 3; art II § 1, cl. 3; amend. XII; Amendment XIV, $\S 2$. Each instance is qualified by the word "citizen." In LUELLA GetTys, The LAW OF Citizenship IN The United StaTes 1 (1934), Gettys points out in the introduction that "inhabitant" and "citizen" were often used interchangeably in the late $18^{\text {th }}$ century; inhabitant does not refer to "alien" and/or "foreigner." Gettys did not define "alien" or "foreigner."

55. The $11^{\text {th }}$ Amendment put a stop to this.

56. It is clear that the federal courts have jurisdiction over any case brought against or by the United States. There is no express disability eliminating a suit between the U.S. and a Foreign Citizen or Subject.

57. Although Foreign Citizens or Subjects could bring a case against fellow Foreign Citizens or Subjects under admiralty/maritime jurisdiction. See The Constitution, Article III section 2.

58. See Mossman v. Higginson, 4 U.S. 12, 14 (1800) (opinion delivered "[b]y the Court," of which Oliver Ellsworth was the sitting Chief Justice); (holding that federal alienage jurisdiction can only occur when "foreigners" or an "alien" are one party, "but a [State] citizen is the other."). Id. Interestingly, Oliver Ellsworth was the sitting Chief Justice of the Supreme Court at this time. Thus, it is reasonable to assume that Ellsworth understood when he drafted the ATS in 1789 that it would be constitutional only if one party were an "alien," and the other a U.S. citizen. See infra note 117 and accompanying text. This would eliminate federal jurisdiction over ATS cases like Sarei v. Rio Tinto, where both parties are foreigners. Sarei v. Rio Tinto, PLC, 550 F.3d 822, 825 (9th Cir. 2008); see also Argentine Republic v. Amerada Hess Shipping Corp., 488 U.S. 428 (1989). This would also make more sense, because there was no reason in 1789 for Congress to force the federal courts to hear cases addressing the plights of parties who may never come anywhere near the United 
1789, Foreign Citizens or Subjects could be involved in litigation with any State, any citizen of a State, with the United States, but not with other Foreign Citizens or Subjects. ${ }^{59}$ Thus, it would be unconstitutional for "aliens" to be both a plaintiff and defendant in the same case under the ATS. ${ }^{60}$

\section{B. The Senate Committee That Debated and Created the Judicial Bill Beginning in April 1789}

After the ratification of the Constitution it was necessary for the First Federal Congress to immediately enact a statute to establish the Federal courts and regulate their jurisdiction and structure, in accordance with Articles I and III. ${ }^{61}$ There had been no national judiciary under the Articles of Confederation, and during the Convention and then the various State ratifications of the Constitution, anti-federalists and federalists alike proposed numerous amendments to Article III, prompting Madison to quiet the controversies by proposing what is now known as the Madisonian Compromise: the promise of a post-Ratification creation of a Congressional Act to detail the judicial branch. ${ }^{62}$ Article III did contain significant provisions organizing and regulating the judiciary, but almost nothing in the text conveyed a specific structure. ${ }^{63}$ Relevantly, the Constitution provided the jurisdictional provisions, and this: that there were to be "such inferior Courts as the Congress may from time to time ordain and establish." 64

With this in mind, on April 7, 1789, just over a month from the Senate's first meeting (but only the day after a quorum was finally achieved), the Senate prepared "to bring in a bill for organizing the Judiciary of the United States." 65 They formed a committee composed of senators Oliver Ellsworth, William Paterson, William Maclay, Caleb Strong, Richard Henry Lee, Richard Bassett,

States-except to forum shop. See, e.g., Moxon v. The Fanny, 17 F. Cas. 942, 947-48 (D. Pa. 1793).

59. See Bradley, ATS and Art. III, supra note 5, at 627.

60. See, supra note 58.

61. Because the members of the Constitutional Convention were unable to decide whether and what type of system of federal courts inferior to the Supreme Court should be created, the Convention agreed to leave these details to Congress-post Ratification; this is well known as the Madisonian Compromise. Paul M. Bator, Paul J. Mishkin, David L. Shapiro, \& Herbert Wechsler, HART AND WECHSLER'S THE FEDERAL COURTS AND THE FEDERAL SYSTEM 11-12 (2d ed. 1973).

62. Id.; Not to be confused with the "great compromise" made during the Federal Convention that gave each state an equal vote in the Senate. See JAKE N. RAKOVE, Original MEanINGS 57-58 (1996).

63. RITZ, supra note 13 , at 4.

64. U.S. CoNST. art. III, $\S 1$; Note that this grant: "Congress may from time to time" establish inferior tribunals, and the "Power" (granted in art. I, $\S 8, \mathrm{cl} .9$ ) Congress had "To constitute Tribunals inferior to the supreme Court," did not demand the creation of such courts, or of a specified structure. The decision to do so as the first action of the first Congress was basically political-to ensure Ratification. See RITZ, supra note 13, at 4-21.

65. Senate Journal, April 7, 1789. 
William Few, and Paine Wingate. ${ }^{66}$ This would be the first act enacted by the First Federal Congress, and records of the committee's debates are-as the Court pointed out in Sosa-less than sparse. Maclay kept his famous journals, which are not helpful regarding any sections or terms pertinent to this discussion. ${ }^{67}$ In fact, Maclay spends more time recounting his irritations and ailments, including the "bluntness" of his memory, ${ }^{68}$ than he does relating happenings in the judicial committee. ${ }^{69}$

There are no records in the Senate Journal alluding to judicial committee meetings, but it first met in the Senate chambers on May 9, 1789. ${ }^{70}$ After exchanging pleasantries of a nature much too familiar for Maclay, the committee was soon interrupted by the meeting of the full Senate. ${ }^{71}$ Two days later, the committee met again; it appears they discussed the judicial bill in detail during both meetings, because Maclay expressed (not for the last time) his dislike for the plan so far: "I do not like it in any part, or rather I generally dislike it, but we will see how it looks in form of a bill." 72 That same day the committee appointed a sub-committee to begin drafting such a bill. ${ }^{73}$

The sub-committee consisted of Senators Oliver Ellsworth, Caleb Strong and William Paterson. Paterson wrote the first nine sections of the Senate's Handwritten Draft of the judicial bill; ${ }^{74}$ Ellsworth, the chairman of the committee, penned sections 10 through 23, relating to jurisdiction; and Caleb Strong and a Senate clerk finished the task through what eventually became section 35 of the Judiciary Act of $1789 .{ }^{75}$ Senator Maclay noted that Oliver Ellsworth was the bill's main architect, and something more: "This vile bill is a child of his, and [Ellsworth] defends it with the care of a parent, even with wrath and anger. He kindled, as he always does, when it is meddled with."76

66. Id.; William Garrott Brown, THE LifE OF OliVER ElLSWORTH 188 (1905).

67. MACLAY, supra note 16 , at 1-134.

68. Id. at 30 .

69. Although many commentators, including Professors Charles Warren and Julius Goebel, question the accuracy of MACLAY'S JOURNALS, their interpretations have been subsequently shown to be errors on their part, not Maclay's: Maclay has been found to be accurate "in all instances." RITZ, supra note 13 , at 192

70. However, a week earlier Ellsworth already had many plans for the judicial bill: In a letter dated April 30, 1789 to Judge Richard Law of the Connecticut Superior Court, Ellsworth asked Law's opinion on many topics covered in the judicial bill, including alienage jurisdiction: The "District Court [should] have original jurisdiction in law and equity, in controversies between foreigners and citizens and between citizens of different states." See BROWN, supra note 66, at 188-89.

71. MACLAY, supra note 16 , at 25.

72. Id. at 30.

73. Id. at 29-30.

74. Section 9 of this initial draft was eventually cut. Consequently, the original $10^{\text {th }}$ section, written by Ellsworth, became the $9^{\text {th }}$ section of the House's Printed Draft, and of the Judiciary Act of 1789.

75. RITZ, supra note 13 , at $22,168,180-83$; Casto, supra note 3, at 498, n 169.

76. MACLAY, supra note 16, at 91-92; See also Mahoney, Note on Hodgson at 731; WILliam 


\section{The First Draft}

The sections of the Judiciary Act of 1789 relevant to this discussion, sections $9,11,12$ and 13, were all originally written by Ellsworth, most likely based on discussions and notes taken during the unreported committee discussions. ${ }^{77}$ In addition to heading the judicial committee and its subcommittee, during this time Ellsworth participated on many other committees, from one "appointed to consider . . the utility of printing the Journals weekly," to another "appointed to wait on the Vice President." ligent and industrious, not to mention eager. ${ }^{79}$ In fact, although he was spread thin, "[n]o one was better qualified to Implement the Constitution's judicial article." $" 80$

Before writing the judicial bill, Oliver Ellsworth had practical experience as an attorney and judge, and extensive legislative and constitutional experience as well. He was born and raised in Connecticut, but attended both Yale and the College of New Jersey (Princeton). Ellsworth read law in a law office for four years and then was admitted to the bar in 1779. His path from local Connecticut Assemblyman in 1773 to the Chief Justice of the Supreme Court of the United States (1796-1800) took him through the Continental Congress (1777-1784), the Connecticut Council of Safety and the Governor's Council, a judgeship on the Superior Court of Connecticut, and, before becoming one of the first U.S. Senators, Ellsworth was a delegate to the Federal Constitutional Convention in Philadelphia. There, Ellsworth actively participated in debates, and helped formulate the "Connecticut Compromise," which resolved a critical debate between the large and small states over representation in Congress. ${ }^{81}$ He was also a member of the committee of detail regarding what later became known as the Supremacy Clause. ${ }^{82}$

As the "father" of the judicial bill, various commentators blame Ellsworth for some of its vagaries. ${ }^{83}$ However, although Ellsworth protected his construction and word choice "with wrath and anger," he did give in to concessions. For example, the Senate's Handwritten Draft of the judicial bill was still being

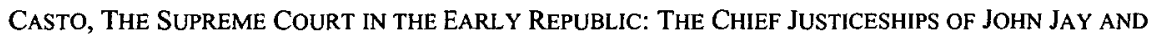
OLIVER ELLSWORTH 27 (1995) (stating that Ellsworth was the judicial bill's "leading projector.")

77. See BROWN, supra note 66 , at 186 . Again, note that the original section 10 later became section 9.

78. Senate Journal, April 14 \& 16, 1789.

79. See generally BROWN, supra note 66 , at $177-81$ (stating Ellsworth's upstanding reputation, and that he was one of the first Senators to arrive in New York on March 4, 1789).

80. CASTO, supra note 76 , at 27.

81. The Supreme Court Historical Society, available at http://www.supremecourthistory.org /02_history/subs_timeline/images_chiefs/003.html (last visited March 3, 2009).

82. RAKOVE, supra note 62, at 173.

83. See Mahoney, Note on Hodgson, supra note 14, at 731-32. 
drafted upon its presentation on June 12, 1789." 84 While reading through his handwritten draft on the Senate floor, Ellsworth made numerous changes and notes in the margins, between lines, and on scraps of paper. ${ }^{85}$ For the most part, however, he barely altered the sections relevant here. ${ }^{86}$

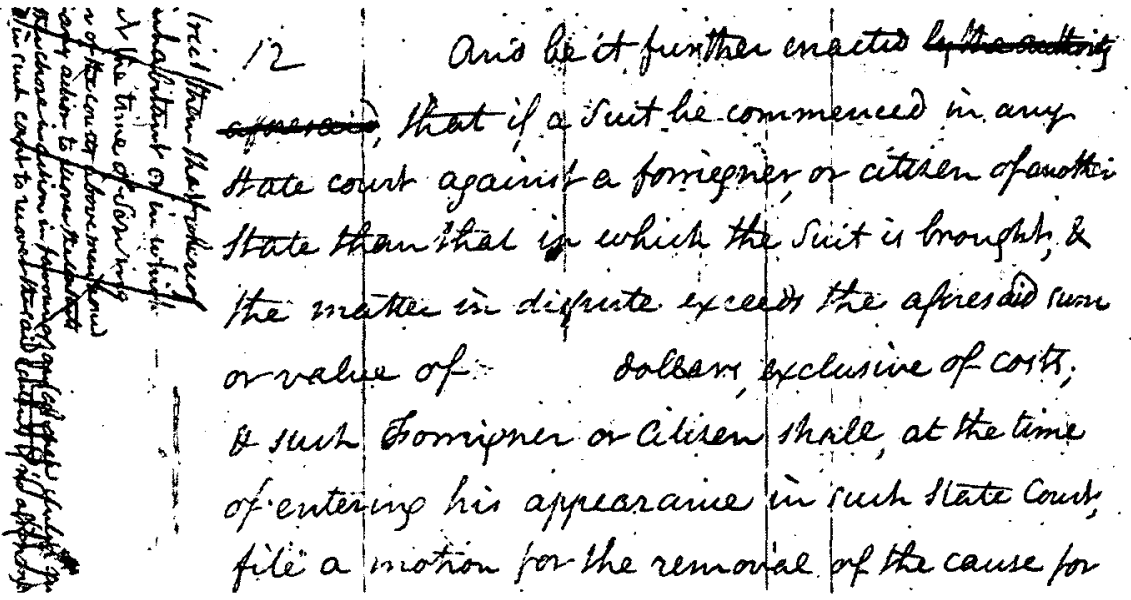

Although the enacted version contains the word "alien" five times, this handwritten version of the bill does not contain that word at all-it contains "forreigner" (note the unique spelling) in the places that later contain "alien."87 The sentence that eventually became the ATS contains the first use of the word "forreigner": The district courts shall have cognizance "of all causes where a forreigner sues for a tort only in violation of the law of nations...." 88 The next use of "forreigner" occurs in section 11: The circuit courts shall have original "cognizance ... where the matter in dispute exceeds ... the sum of 500 dollars $\&$ the United States are plaintiffs or petitioners, or a forreigner or citizen of another state other than that in which the suit is brought, is a party." 89 The third and fourth uses of "forreigner" occur in the first sentence of section 12: "if a suit be commenced in any state court against a forreigner, or citizen of another State than that in which the Suit is brought, \& the matter in dispute exceeds the aforesaid sum of value of dollars, exclusive of costs, \& such Forreigner or Citizen shall, at the time of entering his appearance in such State Court, file a motion for the removal of the cause ...."90

84. Senate Journal, June 12, 1789.

85. See Senate's Handwritten Draft, sections 3-13 and accompanying notes.

86. Id.

87. Id.

88. Senate's Handwritten Draft, 13, 1.27-14, 1.2.

89. Id. at $14,11.15-20$.

90. Id. at $15,11.10-17$ 
The last use of "forreigner" occurs in the first sentence of section 13:

the supreme court shall have exclusive jurisdiction of all controversies of a civil nature, where any of the United States a forreign State is a party, except between a State \& its citizens, \& except also between a State \& citizens of other States or forreigners, in which latter case it shall have original but not exclusive jurisdiction. ${ }^{\text {P }}$

Except for the first instance, the subsequent uses of "forreigner" are accompanied by some version of citizen of another state, reflecting the Constitution's diversity language from Article III, $\S 2 .{ }^{92}$ As noted by Maclay on June 29, 1789, "[Ellsworth] in his diction had varied from the Constitution" during the Senate's second reading of the judicial bill. ${ }^{93}$ When Maclay pointed this out to the Senate, he then claimed that his criticism provoked Ellsworth's anger, prompting Maclay's "vile bill" remark. ${ }^{94}$ Thus, words like "forreigner," for Ellsworth, were possibly shorthand-at least to him-for Constitutional language. ${ }^{95}$

One example of Ellsworth's adherence to the Constitution is his use of the word "controversies" in section 13 in relation to jurisdiction regarding States. ${ }^{96}$ Similarly, he properly used "jurisdiction" in section 13 in relation to the Supreme Court, instead of "cognizance." A7 Although some commentators have defined these terms as interchangeable, Ellsworth's uses accurately reflect the Constitution's minute details. ${ }^{98}$ Where Ellsworth uses "cognizance" in the previous sections, the corresponding clause in Article III did not specify "jurisdiction," but simply read: "The judicial Power shall extend...." Many details in this original draft display Ellsworth's intimate familiarity with the Constitution-reaffirming Professor Casto's claim that Ellsworth was the best qualified candidate to implement the Constitution's judicial article. ${ }^{99}$ However, the question regarding his use of "forreigner" remains unanswered at this point. ${ }^{100}$

91. Id. at 16, 11. 6-13.

92. "The judicial Power shall extend to... Controversies... between a State, or the Citizens thereof, and foreign States, Citizens or Subjects."

93. MACLAY, supra note 16, at 91-92.

94. Id.

95. That is, Foreign Citizen or Subject. See, Lee, supra note 5, at 850 (speculating, "[p]erhaps Ellsworth used the word 'foreigner' [sic] to avoid the appearance of concern one way or the other with whether France would remain a monarchy or become a republic.").

96. "Controversies to which the United States shall be a Party; to Controversies between two or more States..." US CONST. art. HI, $\$ 2$.

97. "[T]he Supreme Court shall have original Jurisdiction." Id. at art. III, § 2.

98. RITZ, supra note 13 , at 185 .

99. See Casto, supra note 76. Ellsworth was also a member of the Constitutional Committee of Detail that drafted Article III. Lee, supra note 5, at 848 .

100. See Casto, supra note 76, at 27 . 


\section{The Senate's Printed Draft}

The next version of the judicial bill, the Senate's Printed Draft, was delivered by the printer, Thomas Greenleaf, to Ellsworth on June 16,1789, six days before the second scheduled reading in the Senate. ${ }^{101}$ This version did not significantly vary from the Senate's Handwritten Draft in any of the pertinent sections, except for the spelling change from "forreigner" to "foreigner." 102

Of the original 250 copies of this printed version, five are known to still exist. ${ }^{103}$ Three are in various libraries, and none of these have handwritten notes on them. ${ }^{104}$ The fourth, John Adams's copy, located in the Boston Public Library, is also unmarked. ${ }^{105}$ The fifth copy, however, located in the Rauner Special Collections Library at Dartmouth College, belonged to Senator Paine Wingate of New Hampshire, a member of the judicial committee along with Maclay and Ellsworth. Wingate used his copy to track changes that occurred during the Senate debates between June 22 and July 17, 1789.106 Wingate's handwritten comments are extremely helpful, and until now, undocumented in relation to the ATS. ${ }^{107}$

Because of the sparse and cryptic Senatorial records, Wingate's copy of the judicial bill is unique and informative because it is the only known copy used by a Senator during the actual deliberations. Professor Ritz, the foremost authority on the various drafts of the judicial bill, briefly noted Wingate's annotations in 1956 , pointing out that many of Wingate's changes "directly reflect amendments reported in the Senate Journal, or reported by Senator Maclay in his diary, or

101. Letter from Ellsworth to Richard Law, (June 15, 1789) Ernst Law Manuscripts, Connecticut Historical Society, Hartford, Conn.

102. Although there are some records in numerous correspondences and in the Senate Journals regarding changes proposed and implemented in this draft, none of them are relevant to this discussion.

103. RITZ, supra note 13 , at 185.

104. 1 Julius Goebel, History of the Supreme Court of the United States, ANTECEDENTS AND BEGINNINGS TO $1801465, \mathrm{n} .27$ (1971) (listing the following libraries: Library of Congress; New York Public Library; Chapin Library at Williams College, Williamstown, Mass.)

105. Id.

106. Id:; see A Bill to Establish the Judicial Courts of the United States (with annotations by Senator Paine Wingate) ((New-York: Printed by Thomas Greenleaf.), (undated) [July 17, 1789]) [hereinafter Wingate's Printed Draft], located in the Rauner Special Collections Library, Dartmouth College, Call No. E 310 .B54. Wingate's annotated draft conforms with Senate Journals and MACLAY'S JOURNALS. RITZ, supra note 13, at 192. Wingate later commented that the bill as passed by the Senate for House approval was in much the same form as when it was when printed in the second week of June, but this is contradicted by the detailed annotations he made on his own personal copy. Letter from Paine Wingate to Nathaniel Peaslea Sargeant, (June 18, 1789) in 4 DHSC 474, supra note 16.

107. Wingate was a member of the Continental Congress before his election to the United States Senate, and was later responsible for enrolling the judicial bill after it was approved by the House. 1 Senate Journal 84. 
extant among the manuscripts." 108 Specific changes related to the ATS, alienage jurisdiction, and Supreme Court original jurisdiction are not detailed in Maclay's Journals, the Senate Journals, or surviving correspondences, but Wingate tracked the Senate's alterations to Ellsworth's precious words relating to all of these topics.

In the section dealing with alienage jurisdiction, section 11, Wingate only struck out and replaced one word: "foreigner" with "alien." 109 In section 12, which deals with removal, Wingate changed both uses of "foreigner" to "alien," along with making the following diversity clarifications: ${ }^{110}$

\begin{tabular}{|c|c|c|}
\hline Printed Draft $^{111}$ & $\stackrel{\text { Wingate's }}{\text { Printed Draft }}^{112}$ & $\begin{array}{c}\text { The Judiciary Act } \\
\text { of } 1789\end{array}$ \\
\hline $\begin{array}{l}\text { "if a suit be com- } \\
\text { menced in any state } \\
\text { court against a for- } \\
\text { eigner, or citizen of } \\
\text { another State than that } \\
\text { in which the Suit is } \\
\text { brought, and the mat- } \\
\text { ter in dispute exceeds } \\
\text { the aforesaid sum of } \\
\text { value of } \\
\text { lars, exclusive of } \\
\text { costs, and such for- } \\
\text { eigner or citizen shall, } \\
\text { at the time of entering } \\
\text { his appearance in such } \\
\text { State Court, file a mo- } \\
\text { tion for the removal of } \\
\text { the cause...." }\end{array}$ & $\begin{array}{l}\text { "if a suit be commenced } \\
\text { in any state court against } \\
\text { an alien, or by [a] citizen } \\
\text { of a state in which the } \\
\text { Suit is brought against a } \\
\text { citizen of another state } 113 \\
\text { and the matter in dispute } \\
\text { exceeds the aforesaid sum } \\
\text { of value of } \\
\text { exclusive of costs, and } \\
\text { such alien or citizen shall, } \\
\text { at the time of entering his } \\
\text { appearance in such State } \\
\text { Court, file a motion for } \\
\text { the removal of the } \\
\text { cause...." }\end{array}$ & $\begin{array}{l}\text { "if a suit be commenced } \\
\text { in any state court against } \\
\text { an alien, or by a citizen of } \\
\text { the state in which the suit } \\
\text { is brought against a citi- } \\
\text { zen of another state, and } \\
\text { the matter in dispute ex- } \\
\text { ceeds the aforesaid sum } \\
\text { or value of five hundred } \\
\text { dollars, exclusive of costs, } \\
\text { to be made to appear to } \\
\text { the satisfaction of the } \\
\text { court; and the defendant } \\
\text { shall, at the time of enter- } \\
\text { ing his appearance in such } \\
\text { state court, file a petition } \\
\text { for the removal of the } \\
\text { cause...." }\end{array}$ \\
\hline Chart z1, Box A & Box B & Box C \\
\hline
\end{tabular}

In section 13, which details Supreme Court original jurisdiction, although Wingate noted alterations to a substantial portion of the latter part of the paragraph, the only relevant substantive change is the substitution, again, of "alien"

108. RITZ, supra note 13, at 185.

109. Wingate's Printed Draft 5, 1.10.

110. This chart will become more relevant later. See infra Part VI.

111. Senate's Printed Draft 5, 11. 34-38.

112. Wingate's Printed Draft 5, 11. 34-38.

113. These changes were made verbatim, as reflected in the House's Printed Draft 1. 
for "foreigner."114 Thus, for all the uses of "foreigner," when used in tandem with a variation of citizen of another state, Wingate noted the change to "alien."

However, in Wingate's copy of the draft of section 9, he did not change "foreigner" to "alien." 115 The sentence that later became the Alien Tort Statute contains the only remaining use of the word "foreigner." Wingate noted alterations of other words in section 9, and to the structure of the last sentence in section 9, which indicates that the Representatives did not simply overlook this section. ${ }^{116}$ Of course, this could simply be an oversight by Wingate, but this is not the case: The engrossed copy of the judicial bill submitted by the Senate to the House on July 20,1789 also did not contain this change, but did contain the other changes tracked by Wingate. ${ }^{117}$ That is, the next draft verifies that Wingate's notes are accurate. Conversely, Wingate's draft is evidence that the printer did not make a mistake by neglecting to change all the instances of "foreigner" to "alien" in the House's Printed Draft of July 23, 1789. Therefore, the Senate purposely left this single use of "foreigner"-for reasons not detailed in any known writings.

Because the Senate did not change this initial use of "foreigner" in the bill- -the only use not in tandem with citizen of another state-both "alien" and "foreigner" appear on the same page. This echoes Hamilton's use of both terms in The Federalist No. 22, and Vining's and Stone's uses in House debates; there was a difference between the terms, and the anticipated audience-in this instance Congress as a whole (if not the entire nation)-was assumed to know what that difference meant.

\section{The House's Printed Draft}

The next draft of the judicial bill was also printed by Thomas Greenleaf; he delivered the first 100 copies on July 23, 1789 for use by the House of Representatives in its discussions. ${ }^{118}$ Neither Professors Ritz nor Goebel located existing original copies of this version, and none could be located other than the unmarked copy in the Library of Congress. ${ }^{119}$ Again, Wingate's relevant annotations to the previous draft were reflected in this new draft; however, some confusion arose in relevant portions.

114. Wingate's Printed Draft 6, 1. 28-29.

115. Wingate's Printed Draft 4, 11. 43-7, 5, 11. 2-3.

116. The changes Wingate made to the draft section 9 most likely occurred on July 15,1789 , during the third reading of the bill. Although more changes occurred, according to Wingate (and reflected in subsequent drafts), the Senate Journal for July 15, 1789 indicates that the only change was: "Section ninth, last line, insert 'issues in'."

117. RITZ, supra note 13, at 187-88; and see House's Printed Draft, 4, 1.6.

118. Letter from Thomas Hartley to Jasper Yeates, (July 23, 1789). Yeates Papers, Historical Society of Pennsylvania, Philadelphia.

119. See 1 GOEBEL, supra note 104. 
Section 11 contains "alien," 120 but according to Wingate, it was supposed to read: "where the matter in dispute exceeds . . the sum of 500 dollars and the United States are plaintiffs or petitioners, or an alien or citizen of another state other than that in which the suit is brought, is a party."121 However, the last part was awkwardly printed as: "or an alien is a party, or the suit is between a citizen ... and a citizen of another State." 122 This mistake was later rectified by the Supreme Court, under Chief Justice Oliver Ellsworth, and subsequent codification.

Section 12 still contained its first use of "alien," but the second was appropriately consolidated with "or citizen" to read, "the defendant." 23 Like section 11, section 13 retained "alien," but was substantially reworded: "[T]he Supreme Court shall have exclusive jurisdiction of all controversies of a civil nature, where a State is a party, except between a State and its citizens; and except also between a State and citizens of other States or aliens." The previous drafts, including Wingate's, included the phrase "or a foreign state is a party" directly following the first use of "State." Because the previous drafts read: "where any of the United States or a foreign state is a party," and because the Court retained exclusive original jurisdiction involving other foreign interests-in cases involving foreign Ambassadors et al-this alteration could be read like the consolidation of "alien or citizen" to "the defendant" in section 12;124 that is, "State" in the House's Printed Draft of section 13, meant any state, whether foreign or domestic.

Lastly, as previously stated, this draft of section 9 retained the only use of "foreigner," in the sentence that eventually became the ATS. ${ }^{125}$

Like the Senate Journals, the House Journals, Annals of Congress and surviving correspondences do not detail House debates regarding any of these provisions. Section 3, which created District Courts, was thoroughly discussed and reported in minute detail in late August and early September $1789,{ }^{126}$ but the later sections regarding jurisdiction were either not debated, which is highly unlikely, or simply not recorded. ${ }^{127}$

The votes on some House amendments to the judicial bill were reported in detail, but most were ignored. For example, on Tuesday September 15, 1789,

120. House's Printed Draft, 4, 1.27

121. Wingate's Printed Draft, 5, 11.8-12

122. Id. at 1.27-28; See also supra note 58.

123. House's Printed Draft at 4,1. 48, 51. Note that in the penultimate sentence of section 12 "alien" was inserted, to refer back to the context of "the defendant" in line 51 . Id. at $5,1.35$; see supra Chart zl, Box C.

124. Id. at 5, $11.45-7$.

125. House's Printed Draft at 4, 1.6.

126. As pointed out supra in Part II, the section 3 debate involving Vining, Stone, Livingston and others was recounted in detail in newspapers and in 1 ANNALS OF CONG. 851-66.

127. See 1 ANNALS OF CONG. 851-933. 
the House Journal indicates a simple insertion of the word " Chestertown' in lieu of 'Eastown." 128 The Journal then lists the names of all forty-three Representatives involved and how they voted on this change. ${ }^{129}$ There is no indication that this was a special alteration. If a vote was required to make this simple alteration, it is more than likely the House required a vote for every amendment. And indeed they might have; that same day other amendments were voted on, but the Journal simply records: "And then, the House having made some progress in the said amendments / Ordered, That the farther consideration thereof be postponed until to-morrow."130 However, nothing was reported the next day, or any day. ${ }^{131}$

It is more likely the votes were not recorded than that the votes never occurred. The House made at least 52 such amendments to the judicial bill, but only detailed the changes or votes approximately four times. ${ }^{132}$ Therefore, much of the House's work on this bill was not reported, creating the poverty of drafting history that haunts us today.

House amendments varied from the first amendment, which simply excised "the federal," leaving "government" in section 1, to the forty-eighth amendment, which involved rewriting ten lines of section 29. The final act contains 35 sections and over 8,500 words, so 52 amendments is not a considerable amount. Judging from the robust attendance indicated by the voting registers, and the fact that each change was most likely voted on in a similar procedure to the Eastown/Chestertown example, each Representative would more than likely be aware of every change.

\section{The Judiciary Act of 1789}

When the relevant portions of sections 11,12 and 13 of the bill were finally enacted in the Judiciary Act of 1789 they were not materially changed from the House's Printed Draft. Other than a few comma splices, section 11 remained confusing, implying suits could occur between Foreign Citizens or Subjects. Sections 12 and 13 did not change at all, except for a comma before "or aliens" in section 13. The only material change occurred in section 9 , in the sentence that eventually became the ATS, where "foreigner" was at long last replaced by "alien." The Judiciary Act of 1789 does not contain the word "foreigner," nor does it contain any variation of the Constitutional phrase "Foreign Citizens or Subjects."

Even though there is no legislative history regarding this change, it did not likely pass under the radar. Representatives like Stone and Vining-and Madi-

128. 1 House Journal 111, supra note 17.

129. Id.

130. Id.

131. Id. at 112-14.

132. 1 House Journal 115, supra note 17. 
son in particular-would have been aware of the change from "foreigner" to "alien" for many reasons, including those discussed above: 1) it was one of only relatively few amendments, 2) they most likely voted on it, 3) the bill was read before the House members at least three times, 4) Madison extensively wrote about alienage jurisdiction, and 4) Edmund Pendleton pointed out this specific sentence to Madison in a letter he received just before the Senate sent the judicial bill to the House. ${ }^{133}$

Considering the error regarding alienage jurisdiction in section 11 , and the deletion of foreign states as parties, the House arguably intended to limit judicial interference with international matters. Explanations range from national security concerns to the promotion of emigration. ${ }^{134}$ This would make the change from "foreigner" to "alien" more likely a matter of similarly limiting jurisdiction over foreign matters; not all foreigners, only those located in United States territories—only aliens-would have rights.

After reading the amended version of the House's Printed Draft to the entire House-for the third time-on September 17, 1789, the Representatives finally passed the bill, reportedly without debate. ${ }^{135}$ The Senate received the amended judicial bill that same day, and put Ellsworth in charge of an evaluation committee. ${ }^{136}$ Ellsworth wasted no time, reporting back to the Senate two days later during a special Saturday session, that his committee accepted most of the House's amendments, except the ninth, sixteenth, forty-first, and fiftysecond; accepting the forty-eighth amendment with certain modifications. ${ }^{137}$ The rejected amendments were not detailed in the record, but the rewritten modification of the forty-eighth was for some reason reported verbatim. ${ }^{138}$

The Senate sent the judicial bill back to the House on Monday, September $21^{\text {st }}$, and the House reconsidered the amendments "as had been disagreed to by the Senate; and adopted them without debate."139 On September 24, 1789,

133. Letter from Edmund Pendleton to James Madison, (July 3, 1789) in 4 DHSC 446, supra note 16. Madison did not read the letter until July 14 or 15 , and he responded on July 15,1789 . See id. at 468. Pendleton also pointed out to Madison how confusing the first sentence of section 9 seemed to him. Id. at 446 . Following this remark, that language was considerably changed, so it seems possible that Madison listened to Pendleton.

134. See infra Part VI.

135. 1 House Journal 113, supra note 17

136. I Senate Journal 81-2.

137. Id.

138. Id. This amendment, unfortunately, is not relevant here. The forty-eighth amendment was made to section 29, so it is conceivable that the relevant amendment to draft section 9 could be the ninth or sixteenth amendment. To discern the number of the "foreigner" to "alien" amendment-in order to make sure this change was not a printing error-I attempted to track the changes from the text of the House's Printed Draft to the text of the Judiciary Act of 1789 , using the assumption that the amendments were made in order. However, due to numerous disconnected changes to sections 3,5 , and 9 , and truly minor changes involving punctuation, capitalization, and dates, it became apparent that this has not been previously attempted because it is impossible, not to mention unreliable.

139. I ANNALS OF CONG. 939; however, the House Joumal indicates that there was some de- 
President Washington signed the bill into law. ${ }^{140}$

IV.

DEFINITIONS OF "ALIEN," "FoREIGNER" AND RELATED TERMS AS OF $1789^{141}$

The meaning of the words "alien" and "foreigner" can come from usage. ${ }^{142}$ Although Thomas Jefferson, Hamilton, Madison and many other writers never use "alien" to describe an individual residing extraterritorially, and consistently use "foreigner" to indicate foreign-born individuals, the dearth of uses further impoverishes the history of these two words. ${ }^{143}$ By far the best indicia of meaning come from established definitions of these terms, which actually assist in comprehending the drafters' intention and understanding of the Judiciary Act of 1789. "Intention connotes purpose and forethought," and in statutory situations like this, the intention is best interpreted from the plain language. ${ }^{144}$ In turn, the best place to gain understanding of the plain language is from the relevant and available dictionaries and treatises of the day.

"Understanding," in contrast to "intention," may be used more broadly to cover the impressions and interpretations of the drafters, and of the legislators who debated and enacted the Judiciary Act of $1789 .{ }^{145}$ Like intention, understanding is best achieved with help from the following definitions, which are the results of an exhaustive search of the most widely used lexicons of the late eighteenth century. ${ }^{146}$

This section differentiates and defines "alien" and "foreigner" and related words using legal, international, and general lexicons available to the First Federal Congress. Unlike modern dictionaries, the treatises used in 1789 did not supply terse, clear definitions. These works commonly used examples and verbose explanations that tend to confuse the twenty-first century reader. ${ }^{147}$

But what is not confusing is that the overwhelming majority of sources

bate regarding the modifications to the forty-eighth amendment. 1 House Journal 115, supra note 17.

140. 1 Senate Journal 87.

141. The sub-sections of Part IV (i.e., A, B and C) detail the relevant definitions in order to support the conclusions in the following introductory section of Part III, and provide ATS practitioners with in-depth, workable sources. However, the meticulous detail and repetition can be exhausting to digest. The casual reader may find it helpful to revisit Parts I and II after these painstaking sub-sections in order to process Parts V and VI more effectively. Or, the casual reader may simply read the following introductory section, then skip to Part V.

142. See RAKOVE, supra note 62 , at 8.

143. See, e.g., infra Part IV, A, C, F, G.

144. See RAKOVE, supra note 62 , at 8.

145. See id.

146. See generally, John D. CoWley, A Bibliography of ABRidgments, Digests, DiCTIONARIES AND INDEXES OF ENGLISH LAW, TO THE YEAR 1800 (1932).

147. See id. at xcii-xciv. 
available to the drafters of the judicial bill define an "alien" as an individual who: 1) is foreign-born, and 2) resides in a sovereign's territory other than the one where he was born. ${ }^{148}$ A "foreigner" is defined as an individual who: 1) is foreign-born, or more specifically, is a foreign citizen or subject, or 2) is a foreign-born individual residing extraterritorially. ${ }^{149}$ The concepts of location and residency were used to differentiate between "alien" and "foreigner" in the eighteenth century, and most definitions-including all of the most popular works-never refer to individuals located extraterritorially as "aliens." 150

\section{A. Legal Definitions}

\section{Blackstone's Commentaries}

It is well established that Sir William Blackstone's Commentaries had a profound influence on the founders, and on the drafters of the judicial bill. ${ }^{151}$ One year before the Declaration of Independence, Edmund Burke remarked in Parliament that the Colonists were relying on the Commentaries. ${ }^{152}$ Relevant House and Senate records indicate a general dependence on the Commentaries for a wide array of legal definitions, and during the Constitutional Convention and the numerous State Ratifications of the Constitution debaters ritualistically referred to Blackstone's work, showing that it was a widely respected and understood source. ${ }^{153}$

Although Thomas Jefferson later proclaimed that the Commentaries were more dangerous than Napoleon's armies, he also described Blackstone's opus as "lucid in arrangement ... correct in its manner ... rightfully taking its place by the side of Justinian's Institutes." 154 Jefferson placed the Commentaries on a list of readings all lawyers should study, referring to the work as "the inimitable Commentaries of Blackstone," and as "the last perfect digest of [chancery and

148. See infra sections IV A-C.

149. Id.

150. Id.

151. See generally Julian S. Waterman, Thomas Jefferson and Blackstone's Commentaries, 27 ILL. L. REV. 629 (1933); Dennis R. Nolan, Sir William Blackstone and the New American Republic: A Study of Intellectual Impact, 51 N.Y.U. L. REV. 731 (1976); Daniel J. BOORSTIN, THE MYSTERIOUS SCIENCE OF THE LAW 1-2, 35 (1941); Lee, supra note 5, at 845-46.

152. Albert W. Alschuler, Rediscovering Blackstone, 145 U. PA. L. REV. 1, 5 (1996); DAVID A. LOCKMILLER, SIR WILLIAM BLACKSTONE 170 (1938) (stating that approximately one thousand copies of the English edition of the Commentaries were sold in the Colonies even before fourteen hundred sets of the American edition sold in 1772).

153. See, e.g., 3 THE DOCUMENTARY HISTORY OF THE RATIFICATION OF THE CONSTITUTION (NY) 169-70, 189, 259, 310, 480 (Merrill Jensen, ed. 1978); James Madison ordered a copy of the COMMENTARIES for the Continental Congress on January 24, 1783. 24 Journals of the Continental Congress 89 (1783).

154. Waterman, supra note 151 , at 636-37. 
common] law."155

During the summer of 1789, Oliver Ellsworth and William Patterson, two of the three authors of the Senate's Handwritten Draft of the judicial bill, cited and relied on the Commentaries in the Senate's discussions of the bill. ${ }^{156}$ According to Maclay, Ellsworth "brought forward Judge Blackstone, and read much out of him" during the judicial bill debates. ${ }^{157}$ Not surprisingly, there exists no record of relevant Senate or House debates specifically referring to Blackstone's understanding of "foreigner" or "alien," but it would be surprising if any of the Senators or Representatives were unfamiliar with Blackstone's treatment of this subject.

Blackstone does not expressly define "foreigner," but his Commentaries supply a definition of "alien" not unlike the modern legal definition. ${ }^{158}$ Before addressing the "alien" definition, however, it is important to detail Blackstone's rare use of and reference to "foreigner." He uses "foreigner" broadly, appropriately referring to an individual who could be located in England or extraterritorially. ${ }^{159}$

Blackstone separated the law into four "books": "Book The First" focuses on the "Rights of Persons," what a modern lawyer might call constitutional law. ${ }^{160}$ Here he addresses the relationships between masters and servants, parents and children, and husbands and wives. In chapter 10 , he specifically addresses the rights "of the People, whether Aliens, Denizens, or Natives,"161 specifying that aliens, not foreigners, "fall under the denomination of the people" who deserve rights within the realm. ${ }^{162}$

Only a few pages prior to this, in Chapter 9, Blackstone differentiates between the terms "alien" and "foreigner" while detailing the rights women had to real property: if a woman with property married a man outside her "parish," her property rights changed, "the law not permitting the separation of husband and wife." 163 Blackstone points out that "if the [husband] be a foreigner, and has no

155. Id.

156. MACLAY'S JoURNALS at 92, 94, supra note 16; see Casto, supra note 3, at 489.

157. MACLAY'S JOURNALS at 92, supra note 16. Ellsworth had personal copy of the first American edition of Blackstone's Commentaries. BROWN, supra note 66, at 22.

158. 1 WiLliam BLACKSTONE, COMMENTARIES ON THE LAWS OF ENGLAND *351-84 (17651769) [hereinafter COMMENTARIES].

159. See generally, id.

160. Alan Watson, The Structure of Blackstone's Commentaries, 97 YALE L.J. 795, 803 (1988).

161. Id. at 354 (emphases added).

162. Id.; In England, denizens were above aliens in that they could own land, but below full subjects in that they could not inherit, or hold office. Id. Thus, while they were technically "subjects" in 1789 in that they owed obedience to the King, their status was unlike (and inferior to) every natural-bom British subject. See JAMES H. KETTNER, THE DEVELOPMENT OF AMERICAN CITIZENSHIP, 1608-1870 5 (1978) (tracing degrees of subjectship under English law).

163. 1 COMMENTARIES *352. 
settlement, her's is suspended during his life."164 Because an English woman had the legal right to marry a man from another country, and accompany him there with leave from the king, the "foreigner" referred to here could be a man simply from another English parish, or a man from-or even residing inanother country; Blackstone makes no differentiation, and therefore the broad term "foreigner" arguably encompasses both. ${ }^{165}$ But his use of the word "foreigner" here, only a few pages before his use of the word "alien," makes a similar differentiation as made by, for example, Hamilton in The Federalist No. 22; namely, that there is a difference between the terms.

In Chapter 22 of "Book The Third," which focuses on "Private Wrongs," Blackstone again makes this distinction when he uses "foreigner" when referring to an individual who could be located in or outside the realm. ${ }^{166}$ While discussing London's jurisdiction when the city itself is the plaintiff, it did not matter to Blackstone "whether the defendant be a citizen of London or a foreigner." 167 Because the city commonly sued defendants, usually merchants based on the Continent, this reference meant defendants could be citizens of York or citizens of Milan. Again, Blackstone makes no differentiation and "foreigner" here simply means any individual not residing in the particular city or country mentioned.

Blackstone's "Book The Fourth" details rules of law governing "Public Wrongs," and here his use of "foreigner" and "foreign" is somewhat abstruse. ${ }^{168}$ In Chapter 5 Blackstone refers to a topic familiar to all ATS jurists and commentators:

And as during the continuance of any safe-conduct, either express or implied, the foreigner is under the protection of the king and the law; and, more especially, as it is one of the articles of magna carta, that foreign merchants shall be intitled to safe-conduct and security throughout the kingdom; there is no question but that any violation of either the person or property of such foreigner may be punished by indictment in the name of the king. 169

164. Id.

165. Id.

166. 3 COMMENTARIES *335.

167. Id.

168. See generally, 4 COMMENTARIES. This book details the motivations and means of domestic crimes and their punishments as they apply to English citizens and subjects.

169. Id at $* 70$ (emphases added). Moreover, in 1789 , safe-conducts applied only in territory under the effective control of the sovereign. See EMMERICH DE VATTEL, THE LAW OF NATIONS; OR PRINCIPLES OF THE LAW OF NATURE: APPLIED TO THE CONDUCT AND AFFAIRS OF NATIONS AND SOVEREIGNS 68, 479 (1787) (obligation of State to ensure safe conduct applies only "where any of [its] troops may be," i.e., in its territory or where it has de facto control by virtue of its military presence); Lee, supra note 5, at 872 (explaining that "a safe conduct signified a sovereign obligation ... to prevent injury to the person or property of an alien within [a State's] territory and also abroad where it had a military presence."). In addition, international law recognized the so-called "international minimum standard," under which States were obliged to treat aliens (foreigners residing in their territory) with a certain minimum level of decency. PETER MALANCZUK, AKEHURST'S MODERN INTERNATIONAL LAW $256\left(7^{\text {th }}\right.$ ed. 1997); See Restatement (Third) Foreign Relations $\$ 711$. 
As used here, "foreigner" refers to an individual who is not a subject of the king; that is, a person not simply from another English city or parish, as above, but specifically from somewhere beyond England's territories. Complicating this, the sentence refers to the person in question as a "foreigner" while that person is within English territory; that is, "under the protection of the king." 170

It can inferred from this implied residence that "foreigner" describes a foreign-born individual now residing in England, but this is not the case. The offence committed by English citizens or subjects against "such foreigner may be punished by indictment in the name of the king, whose honour is more particularly engaged in supporting his own safe-conduct." ${ }^{771}$ In other words, the king was willing to exchange safe-conduct through his realm for the assurance from other countries for safe-conduct for himself (his merchants, shipwrecked sailors, ambassadors, etc). The "foreigner" is not a resident, but only passing through for trade, safety, or ambassadorial reasons, and therefore remained, as Blackstone later points out, a "stranger" to the realm. ${ }^{172}$ Considering Blackstone's broad uses of "foreigner," it is likely he used it broadly here as well, to refer to foreign citizens or subjects that may or may not still be in England, or because "foreigner" would include foreign ambassadors, where the term "alien" would not. ${ }^{173}$

Blackstone referred to enemy soldiers as "the subjects of foreign powers with whom we are at open war," and to marauders as "foreign pirates or robbers." 174 Thus, whether a legal or illegal invader, this type of "foreigner" is not referred to in the Commentaries as an "alien"; as part of "the People."

Blackstone defines "alien" in Chapter 10 of "Book The First," 175 entitled "The Rights of Persons ... of the People, Whether Aliens, Denizens, or Natives." The introduction, "I now proceed to consider such persons as fall under

However, if an alien's right to this level of treatment was infringed, the sole remedy afforded by international law was for the alien's home State to bring a claim for compensation against the wrongdoer's State. Id. at 256-57; See also Barcelona Traction, Light and Power co. Ltd, 1970 ICJ 3, 4445. No international law claim lied directly against the persons responsible for the violation.

170. Today known as a "transient alien." See The OXFord Dictionary OF LAW 23.

171. 4 COMMENTARIES *70 (emphasis added).

172. Id.

173. Blackstone referred to ambassadors as "foreign embassadors," and does not include them in his definition of who is an "alien." See 1 COMMENTARIES *351-84. Moreover, Professor Lee points out five solid reasons why the First Federal Congress "distinguished a private alien from an ambassador or a public minister for purposes of a jurisdictional statute" like the ATS. Lee, supra note 5, at $851-58$.

174. 4 COMMENTARIES *84; Also note that when Blackstone described who qualifies as a victim of homicide, he said: "without regarding whether the party slain was killed openly or secretly, or whether he was of English or foreign extraction." Id. at 196. Since no one is likely restricted from being a homicide victim, this use of "foreign" is broad enough to encompass anyone who is not English.

175. 1 COMMENTARIES *351-84. 
the denomination of the people," 176 indicates that only aliens, denizens, and natives make up the population of England that deserves later specified rights. "The first and most obvious division of the people," Blackstone asserts, "is into aliens and natural-born subjects. Natural-born subjects are such as are born within the dominions of the crown of England, that is, within the ligeance, or as it is generally called, the allegiance of the king":

and aliens, such as are born out of it. Allegiance is the tie, or ligamen, which binds the subject to the king, in return for that protection which the king affords the subject. The thing itself, or substantial part of it, is founded in reason and the nature of government; the name and the form are derived to us from our Gothic ancestors. Under the feodal system, every owner of lands held them in subjection to some superior or lord, from whom or whose ancestors the tenant or vasal had received them: and there was mutual trust or confidence subsisting between the lord and vasal, that the lord should protect the vasal in the enjoyment of the territory he had granted him, and, on the other hand, that the vasal should be faithful to the lord and defend him against all his enemies. ${ }^{177}$

Additionally, this "allegiance" did not have to be expressed: "the subject is bound to his prince by an intrinsic allegiance, before the superinduction of those outward bonds of oath, homage, and fealty; which were only instituted to remind the subject of this his previous duty, and for the better securing it's [sic] performance." 178 That is, "all subjects are equally bounden to their allegiance, as if they had taken the oath." 179

The alien, however, was only "bounden" to the sovereign during the alien's residence in the sovereign's territory. ${ }^{180}$ Once the alien leaves "the king's dominion and protection," Blackstone stops referring to the "alien" as such, using the word "stranger": hence the "stranger transfers himself from the kingdom to another," losing his allegiance. ${ }^{181}$ That is, once the individual is out of the king's protection, he is no longer an "alien," but a "stranger" or "foreigner." 182

In the final example of Blackstone's use of the word "foreigner," he refers to monks who populated "alien priories" in England's past as "foreigners." 183 An alien priory was a monastic establishment owing obedience to a motherabbey in a foreign country, ${ }^{184}$ and was therefore not under the king's protection,

176. Id. at *354.

177. Id.

178. Id. at $* 357$

179. Id.

180. Id. at $* 358$.

181. Id. (emphasis added).

182. Id. See Talbot v. Janson, 3 U.S. 133 (1795) (stating that an individual who severs allegiance but remains in the territory is referred to as an "alien.").

183. 1 COMMENTARIES *374.

184. $O E D$, at "alien priory"; Cunningham's 1783 Law Dictionary defines "alien priories" as "those cells of the religious in England which belonged to foreign monasteries." I TIMOTHY Cunningham, a New and Complete law-Dictionary, or, General Abridgment of the 
and consequently its foreign-born inhabitants would not be "aliens"; as Blackstone clarifies, the priories "were filled by foreigners only"; not "aliens." 185 Ambassadors fall into a similar category, since they continue to owe allegiance only to their sovereign, and embassies-like priories-were considered extensions of the ambassador's country. ${ }^{186}$ Therefore, in the earlier reference to "foreigners" regarding safe-conducts, some of these travelers, especially merchants, could have been referred to as "aliens," but since others requiring safe-conduct could be the sovereign itself, ambassadors and/or ministers, or even priory-dwelling monks, the broader term, "foreigner," encompassed all. Thus, for Blackstone the term "alien" was a subset of the term "foreigner."

Therefore, according to Blackstone, an "alien" is an individual who: 1) is foreign-born, or is a foreign citizen or subject, ${ }^{187} 2$ ) resides (temporarily or otherwise) in a sovereign's territory other than the one where he was born, 3) is expressly or impliedly bound to the sovereign in exchange for protection, and 4) therefore does not owe obedience to, or is legally dependent upon, a foreign sovereign.

A "foreigner": 1) could have all the aforementioned characteristics of an "alien," 2) could be an invading soldier, robber, or pirate, ${ }^{188}$ or 3) a priorydwelling monk, an ambassador, or even a prince, ${ }^{189}$ or 4 ) any foreign-born individual located extraterritorially, or 5) could be an individual residing in a different city or parish than the one mentioned.

The main difference between "alien" and "foreigner" for Blackstone revolves around residency: an "alien" resides in a sovereign's realm other than the one in which the alien was born, where a "foreigner" can reside as such, but can also reside extraterritorially or simply not deserve or expect protection.

Residency is the basis for citizenship/subjectship for Blackstone: "Naturalborn subjects are such as are born within the dominions of the crown of England." 190 Because of this incipient residency, the English subject was granted

LAW, title “Alien" (unpaginated) ( $3^{\text {rd }}$ ed. 1783) [hereinafter CUNNINGHAM's LAW DiCTIONARY].

185. Id.

186. See 37 American State Papers Miscellaneous 21, 26, 34 (1790): in 1790, U.S. Attorney General Edmund Randolph was asked by the $2^{\text {nd }}$ Session of the First House for his interpretations of various sections of the Judiciary Act of 1789. Randolph's interpretation of jurisdiction relating to Ambassadors and other public ministers was that these individuals could only be plaintiffs in federal court, because "according to the law of nations, the diplomatic representatives of sovereigns cannot be sued in the courts of a foreign potentate." Consuls and vice-consuls, on the other hand, could be plaintiffs and defendants. Id. at 26. Randolph's interpretation was later approved and clarified by the Supreme Court in Schooner Exchange v. McFaddon, 7 Cranch 116, 135 (1812).

187. Later uses in this article of "foreign-born" in this context should be read as: "foreign-born, or is a foreign citizen or subject."

188. These individuals would not expect or deserve the sovereign's protection.

189. Theses individuals would not expect or deserve the sovereign's protection either, because they would be "bounden" to the foreign sovereign.

190. 1 COMMENTARIES *354. 
more rights than either denizens or aliens. ${ }^{191}$ Because of their post-birth residency, aliens and denizens were also granted certain rights, but less than naturalborn subjects. ${ }^{192}$ Because of non-residency, the "foreigner" who does not gain protection from this sovereign, nor owe the sovereign allegiance, has even less, if any, rights as a person. ${ }^{193}$ According to Blackstone, this category of individuals does not "fall under the denomination of the people" who deserve rights within the realm. ${ }^{194}$ Any rights they have are derived from their relationship with their sovereign, who in turn has a relationship with the other sovereign; for example, when one sovereign allows safe-conducts in exchange for like treatment.

\section{Viner's Abridgment}

Charles Viner's Abridgment of Law similarly differentiates between the terms "foreigner" and "alien." 195 Viner's 23 volume abridgement, first published from 1741 to 1756 , was well received and respected in England and the Colonies, and continues to be "an invaluable work of reference." 196 "[A] lot of American law," Professor Goebel concludes, "came out of Bacon's and Viner's Abridgments," 197 and Viner's, in particular, was located in "many colonial law libraries," including John Adams's personal collection. ${ }^{198}$

Although the various House and Senate records do not refer to Viner's Abridgment, the Supreme Courts of Pennsylvania, New Jersey, and Maryland relied on Viner's various volumes countless times in the years surrounding the ratification of the Constitution. ${ }^{199}$ U.S. Supreme Court justices, including

191. The contract between a natural-born subject and the sovereign is considered more valuable than the contract between alien and sovereign: "For, immediately upon [the natural-born subject's] birth, they are under the king's protection; at a time too, when (during their infancy) they are incapable of protecting themselves. Natural allegiance is therefore a debt of gratitude; which cannot be forfeited, cancelled, or altered, by any change of time, place, or circumstance, nor by any thing but the united concurrence of the legislature. An Englishman who removes to France, or to China, owes the same allegiance to the king to England there as at home." $I d$. at $* 357$. The rights granted to natural-born subjects that aliens do not enjoy are detailed in the COMMENTARIES. Id. at *351-84.

192. See id. at *360-63.

193. See id. at*351-84.

194. See id. at $* 354$.

195. See 13 Charles VINER, ABRIDGMENT OF LAW AND Equity OF THE LAW OF ENGLAND, 414-1 5 ( $2^{\text {nd }}$ ed. 1790) [hereinafter VINER'S ABRIDGEMENT].

196. Peter de Bolla, The Time of Law: Eighteenth-Century Speculations, SuBSTANCE 35.1, 52 , 53 (2006), available at http://muse.jhu.edu/journals/substance/v035/35.1 debolla.html (last visited March 3, 2009).

197. Julius Goebel, Ex Parte Clio, 54 ColUM. L. Rev. 450, 455 (1954).

198. H. Johnson, IMPORTED EIGHTEENTH-CENTURY LAW TREATISES IN AMERICAN LIBRARIES 1700-1799 59 (1978); Adams's Library collection, available at http://www.johnadamslibrary.org /search/books/?author=viner.

199. Especially Pennsylvania's highest court, which cited "Vin. Abr." over 50 times between 1789 and 1799. For eight of these years Jasper Yeates was an associate justice; 14 years earlier he 
Oliver Ellsworth's court, also cite to "Vin. Abr." numerous times. 200

Viner uses 20 pages to detail and define "alien" in Volume II, but only devotes half a page to "foreigners" in Volume XIII. ${ }^{201}$ In this short space, however, Viner does not confuse "alien" with "foreigner." Thus, because he devotes space to both terms, and does not use one term to define the other, Viner indicates a clear difference between the terms.

The first of Viner's two "foreigner" examples concerns an alien defendant, Colley, a Frenchman residing in England. ${ }^{202}$ Colley transported his principals' goods from France to England, delivering and allegedly selling them to English merchants without reimbursing the principals. 203 These mysterious principals were French citizens located in France, and Viner refers to them as "being all foreigners." 204

The second and last example under "foreigner" involves a Dutch plaintiff suing her English husband. ${ }^{205}$ The Dutch wife remained in Holland with the couple's children while using an agent to get monetary support from her husband, who resided in London. Like he does in his first example, Viner refers to the wife, a foreign-born individual residing extraterritorially, as a "foreigner," not an "alien," 206 which is in line with Blackstone's residency explanation.

Viner's "alien" discussion is also in line with this residency explanation. Conversely to Blackstone, Viner begins his "alien" discussion with an alien's personal rights, mostly regarding property and division, which are echoed (in some cases verbatim) by Blackstone. ${ }^{207}$ Viner then supplies a definition of "alien" before discussing topics including "Naturalization" and "What Actions Alien may have, and in what Cases, and where": "Alien signifies one born in a strange country, under the obedience of a strange prince or country."208 Taken out of context, this definition may imply no residency requirement for an indi-

sat on Pennsylvania's convention that ratified the Constitution of the United States; see, e.g., Thompson v. Musser, 1 U.S. 458 (1789); Respublica v. Le Caze, 1 Yeates 55 (Pa. 1791).

200. See, e.g., Bingham v. Cabbot, 3 U.S. 19, 20 (1795); Brown v. Van Braam, 3 U.S. 344, 356 (1797); Glass v. Sloop Betsey, 3 U.S. 6, 7 (1794); Georgia v. Brailsford, 3 U.S. 1, 3 (1794); Clarke v. Russel, 3 U.S. 415, 421 (1799); Sims v. Irvine, 3 U.S. 425, 433 (1799).

201. 2 VINER, VINER'S ABRIDGEMENT at 257-77; 13 VINER, VINER'S ABRIDGEMENT at 414-15.

202. Id. at 414 (finding that Colley remained in England "to keep his body from arrests" in France).

203. Id.

204. Id.

205. Id. at 415 .

206. Id.

207. See, e.g., 2 VINER, VINER's ABRIDGEMENT at 257 , \& 3; see also 1 COMMENTARIES *360. On Viner's death in 1756, shortly before the last volume of his work hit bookstores, Viner's estate and the proceeds from the sales of the Abridgment went to Oxford to establish the Vinerian Scholarships and the Vinerian chair of English law, first held by Blackstone. William Blackstone, Introduction to the Commentaries *29.

208. 2 VINER, VINER'S ABRIDGEMENT at 262, § 14. 
vidual to be considered "alien." However, Viner's first use of "strange" in the definition implies that the alien in question is from somewhere else, somewhere "strange" or foreign, and is therefore presently located somewhere familiar; that is, in England. The context makes this more likely because of the discussion of English jurisdiction that follows, and because the discussion concentrating on property rights leading up to this definition deals exclusively with rights within England; including, among other examples, "[i]f an alien friend be a merchant, he may purchase a lease for years of a house for his habitation, and the king shall not have this so long as he inhabits there." 209 This condition, requiring the "alien" to continue living in the sovereign's realm or lose his property rights, is repeated throughout Viner's work, further establishing the residency requirement and its relation to personal rights, detailed by Blackstone and others.

Viner was very clear regarding residency in relation to an alien's right to sue. In his discussion of "alien enemy," Viner points out that "suing is but a consequential right of protection." 110 As a consequence of this, an alien "may bring action personal, and shall be answered," and therefore not disabled due to his birth in a foreign land. ${ }^{211}$ Viner supplies a familiar example of "action personal" when he discusses safe-conducts under "alien," pointing out, like Blackstone, that foreign merchants deserve the sovereign's protection in such cases. ${ }^{212}$ But unlike Blackstone, Viner points out that suing for safe-conduct violations is not a tort covered by "the law of the land," but that the "alien . . . may sue here, and it shall be determined according to the law of nature in the Chancery." 213 That is, like the ATS, the law of nations is employed in cases like this because of the aforementioned traditional relationship between sovereigns that leads to reciprocal protection of foreign merchants, ambassadors, princes, etc. Therefore, this action is to be brought by the alien only against "the people" under the king's protection, and where the violations occurred within that king's realm. ${ }^{214}$

Both Viner and Blackstone define an "alien" as an individual who: 1) is foreign-born, and 2) resides in a sovereign's territory other than the one where he was born. Unlike Blackstone, Viner's "foreigner" definition is less complicated. A "foreigner": 1) is foreign-born, or more specifically, is a foreign citizen or subject, and 2) resides extraterritorially. ${ }^{215}$ Again, Viner and

209. 2 VINER, VINER'S ABRIDGEMENT at $257, \S 3$.

210. Id. at $273, \S 15$.

211. Id. at $272, \S 6$.

212. Id. at $271, \S 3$.

213. Id.

214. Id.; see 4 COMMENTARIES *70. In this same section, "What Actions Alien may have, and in what Cases, and where," Viner defines other torts an "alien" may sue for in English courts. He includes "an action of debt upon a bond, and for personal things," which includes actions for "denying [the alien] trade and traffic." 2 VINER, VINER'S ABRIDGMENT at 272-73, $\S 14$. Following this section, he includes defamation and more generally, "trespass." Id. at 274, $\S \S 6,7$.

215. At least in Holland and France. 
Blackstone use the concepts of location and residency to differentiate between "alien" and "foreigner": Viner does not refer to individuals located extraterritorially as "aliens," nor does he refer to "foreigners" as persons located within the realm.

\section{Cunningham's Law Dictionary}

The 1764 and 1783 editions of Timothy Cunningham's Law Dictionary similarly define "alien," but for the most part ignore "foreigner."216 Along with using Blackstone's Commentaries, James Madison ordered a copy of Cunningham's Law Dictionary for the Continental Congress. ${ }^{217}$ In fact, the only dictionary he ordered was Cunningham's. ${ }^{218}$ Although referred to as a "dictionary," Cunningham's work is more similar to Viner's Abridgment than a concise collection of definitions. ${ }^{219}$

This compilation of English common and statutory law and definitions has been considered " $[t]$ he first dictionary which aimed at completeness as regards [to] legal terms." 220 It was one of the most popular comprehensive English dictionaries of the late eighteenth century, ${ }^{221}$ and was found in many personal libraries, including those of Thomas Jefferson and John Adams. ${ }^{222}$ Like the

216. 2 CUNNINGHAM, CUNNINGHAM'S LAW DictionaRY, title "Foreigner" (unpaginated); Cunningham was a prolific writer who, in addition to his dictionary, wrote a history of the Inns of Court, an introduction to English law and its constitution, a set of case reports, and, among other works, a book on negotiable instruments and insurances; see also 1 CUNNINGHAM, A NEW AND COMPLETE LAW-DICTIONARY, OR, GENERAL ABRIDGMENT OF THE LAW, title "Foreigner" $\left(1^{\text {st }} \mathrm{ed}\right.$. 1764-65).

217. 24 Journals of the Continental Congress 89 (1783) (ordering both CunNINGHAM's LAW DICTIONARY and CUNNINGHAM'S LAW OF EXCHANGE).

218. Id.; Justice Clarence Thomas used this dictionary along with two separate editions of Giles Jacob's, A NEW LAW DICTIONARY (see infra note 244,) while searching for original meaning in both United States v. Lopez, 514 U.S. 549 (1995) and United States v. Webster Hubbell, 120 S. Ct. 2037 (2000). Gary L. McDowell, The Politics of Meaning: Law Dictionaries and the Liberal Tradition of Interpretation, 44 AM. J. LEGAL HIST. 257 (2000).

219. The full title is: A New and COMPLETE Law-Dictionary, OR, GeNERAL Abridgment OF THE LAW: ON a MORE ExTENSIVE Plan than aNy LAW-DictionaRY Hitherto Published. CONTAINING NOT ONLY THE EXPLANATION OF THE TERMS BUT ALSO THE LAW ITSELF, BOTH WITH REgARD tO THEORY AND PRACTICE. ALSO THE INTERPRETATIONS OF THE WORDS MADE USE OF IN OUR ANCIENT CHARTERS, CHRONICles, Histories, RECORDS, AND REGisters. TOGETHER WITH SUCH KNOWLEDGE AS IS NECESSARY TO ILLUSTRATE THE ANTIQUITY OF THE LAW AND OUR ORIGINAL GOVERNMENT AND CUSTOMS IN FORMER TIMES. I CUNNINGHAM, CUNNINGHAM'S LAW DICTIONARY, title page (unpaginated).

220. FREDERICK C. HiCKS, MATERIALS AND METHOdS OF Legal ReSEARCH $247\left(3^{\text {rd }} \mathrm{ed} .1942\right)$.

221. 12 HOLDSWORTH, A HISTORY OF ENGLISH LAW 177 (1938) (finding that the three most popular dictionaries written in the late eighteenth century were Cunningham's, Jacob's $A$ New Law Dictionary, and WILLIAM MARRIOTT's, A NEW LAW DICTIONARY (1797) (note that the latter was not available during the writing of the Judiciary Act of 1789 and is therefore not relevant.)).

222. E. Millicent SOWERBy, Catalogue of THE LibraRy of THOMAS JefFerson (1814); Adam's library collection, available at http://www.johnadamslibrary.org/search/books/?author= cunningham. 
Commentaries and Viner's Abridgment, Cunningham's Law Dictionary was also contemporaneously used by various American Supreme Courts for clarification of legal terms. ${ }^{223}$

Cunningham's commentary on "foreigner" is terse: "Foreigners, Though made denizens or naturalized here, are disabled to bear offices in the government, to be of the Privy council, members of Parliament, \&c. by acts of settlement of the crown." 224 However, Cunningham does provide informative and familiar definitions for "Foreign": "Strange, outlandish, or of another country." 225 Taken in context, his definition of "Foreign attachment" is also informative, indicating that the "foreigner" is not residing locally: "an attachment of a foreigner's goods found within a liberty, or a city, for the satisfaction of some citizens to whom the foreigner is indebted."226 The goods were to be attached because the foreigner was not located within the jurisdiction.

Under "alien," Cunningham uses the word "foreigner" only once, and, as in Viner's Abridgement, it signifies individuals located extraterritorially: "if any manufacturer or artificer ... go into any country out of his majesty's dominions, there to use or exercise, or teach any of the said trades or manufactories to foreigners ... [he] shall not return within this realm within six months."227 From the latter two uses, for Cunningham a "foreigner" is not an individual residing locally. 228

Cunningham uses seven pages to define "alien," reflecting both Blackstone's and Viner's definitions, and clarifying the legal origin of the idea of residency for an "alien."229 Cunningham cites Sir Edward Coke's 1608 opinion in Calvin's Case for the basis of: "alien ... [i]s one born out of the ligeance of the King," and for "alien ... signifies one born in a strange country." 230 Cunningham adds that Coke held that "alien ... is usually taken for the contrary to a denizen, or natural subject; that is, one born in a strange country, and never here enfranchised."231 This does not define an "alien" simply as a foreign-born individual, but as an individual "born in a strange country, and" not enfranchised within the realm where he currently resides. By pointing out that the "alien" is "here," and that the term is "contrary to a denizen, or natural subject," this puts

223. See, e.g., Adams v. Woods, 6 U.S. 336 (1805); Gorgerat v. M'Carty, 1 Yeates 94 (Pa. 1792); Ingram v. Hall, 2 N.C. 193 (N.C. 1795).

224. 2 CUNNINGHAM, CUNNINGHAM's LAW DictionaRY, title "Foreign" (unpaginated).

225. Id. at title "Foreign."

226. Id. at title "Foreign Attachments."

227. 1 CUNNINGHAM, CUNNINGHAM's LAW DictionaRY, title "Alien" (unpaginated).

228. Although they are helpful to show usage in line with other definitions.

229. Id.

230. Id. Not all individuals born "out of the ligeance of the King" or in "a strange country" are considered "alien": "Yet a man born out of the land, so it be within the limits of the King's obedience, beyond the seas, or of English parents out of the King's obedience, is not accounted an alien, but a subject." Id ; 2 Viner, VINER'S ABRIDGEMENT at 262, $\S$ 12-18; 1 COMMENTARIES *361-61.

231. Id. (emphasis added). 
"alien" in the category—detailed by Blackstone—of "the People" under a particular sovereign's protection. ${ }^{232}$ Taken in context, Cunningham's definition mirrors Viner's because it comes after and before specific discussions of rights only within the realm, therefore further indicating that "alien" signifies an individual residing locally — somewhere not "strange," but familiar. ${ }^{233}$

Unlike Viner and Blackstone, Cunningham further explains his "alien" definition:

An alien is one born in a strange country and different society, to which he is presumed to have a natural and necessary allegiance; and therefore the policy of [England's] constitution has established several laws relating to such a one; the reasons whereof are, that every man is presumed to bear faith and love to that prince and country where first he received protection during his infancy; and that one prince might not settle spies in another's country; but chiefly that the rents and revenues of the country might not be drawn to the subjects of another. ${ }^{234}$

Therefore, the "alien" is "here," settled in "another's country," and could garner undeserved support from the sovereign if left unchecked.

Cunningham cites many of the same examples that Viner does regarding an alien's right to sue in English courts, but supplies the reader with a reason in addition to residency (although it is related): "The reason why an alien . . . is allowed to maintain a personal action ${ }^{235}$ is, because he would otherwise be incapacitated to merchandise, which may be as much to our prejudice as his."236 Other than protecting an individual in exchange for obedience, this economic reason to secure the flow of merchandise into England apparently comes from Hale: "Lord chief justice Hale says, that the laws of England rather contracts than extends the disability of aliens, because the shutting out of aliens tends to the loss of people, which laboriously employed are the true riches of any country."237 The "alien" is a desired part of "the People" and adds to the sovereign's "riches," and this can only be accomplished by allowing others to reside, even temporarily, within the sovereign's realm.

Therefore, Cunningham's definition accords with Blackstone's and Viner's: An "alien" is an individual who: 1) is foreign-born, and 2) resides in a sovereign's territory other than the one where he was born, and therefore under the sovereign's protection -in one way or another (for residency or trade rea-

232. See 1 COMMENTARIES *355.

233. See generally 1 CUNNINGHAM, CUNNINGHAM's LAW DictionaRY, title "Alien" (unpaginated).

234. Id.

235. Cunningham echoed the "personal actions" mentioned by Viner, including a thorough treatment of defamation, and elaborated on trespass: "aliens... are entitled for all personal actions for the support of their credit and trade, and other actions likewise, as assault and battery, for assaults done upon themselves." I Bulst. 134, cited in I CUNNINGHAM, CUNNINGHAM's LAw DiCTIONARY, title "Alien" (unpaginated).

236. Id.

237. I Vent. 427, cited in 1 CUNnINGHam, Cunningham's Law Dictionary, title "Alien" (emphasis added). 
sons). Unlike Viner, Cunningham does not specifically define "foreigner," but his rare use of the word does fit into Viner's definition, as does Blackstone's.

Moreover, Viner and Cunningham do not refer to individuals located extraterritorially as "aliens." In fact, under his definition of "Enemy," Cunningham makes this clear distinction between "alien" and "foreigner":

Enemy ... [i]s properly an alien or foreigner, who in a public capacity, and in an hostile manner, invades any kingdom or country; and whether such persons come hither by themselves, or in company with English traitors, they cannot be punished as traitors, but shall be dealt with by martial law. ${ }^{238}$

By mentioning "alien or foreigner," Cunningham makes the same differentiation Hamilton and Representatives Vining and Stone did. ${ }^{239}$ There is a difference: "alien or foreigner." Cunningham differentiates here because although "foreigners" will "be dealt with by martial law," on the other hand, "aliens," "living under the protection of the King . . may be punished only as traitors." 240 An "alien," because of the status as part of "the People," will be punished differently than a "foreigner," but in the same manner as a denizen or citizen/subject.

\section{Jacob's New Law Dictionary}

In Giles Jacob's New Law Dictionary, the author also does not refer to individuals located extraterritorially as "aliens," and to differentiate between "alien" and "foreigner," Jacob uses the same "alien or foreigner" phrase as Cunningham. ${ }^{241}$ Although Jacob has been dismissed by some modern commentators as a writer of "undistinguished works," 242 he was one of the most prolific and widely recognized compilers of legal texts in the late eighteenth century. ${ }^{243}$ His dictionary could be found alongside the works of Blackstone, Viner, and Cunningham on Jefferson's and Adams's shelves, and was contemporaneously in twice as many law libraries as the second most popular

238. I Cunningham, CUNnINGHam's Law Dictionary, title "Enemy" ( $1^{\text {st }}$ ed. 1764-65) (unpaginated) (emphases added).

239. See supra Part II.

240. I CUNNINGHAM, CunNINGHAM's Law DictionaRY, title "Enemy."

241. The "Enemy" definition is verbatim except for a comma after "country" instead of a semicolon; Jacob's dictionary first appeared in print in 1729, decade's before Cunningham's (1764)and this definition is taken from the following: GILES JACOB, A NEW LAW-DICTIONARY: CONTAINING THE INTERPRETATION AND DEFINITION OF WORDS AND TERMS USED IN THE LAW, title "Enemy" $\left(8^{\text {th }}\right.$ ed. 1762$)\left(9^{\text {th }}\right.$ ed. 1772$)\left(10^{\text {th }}\right.$ ed. 1782) (unpaginated) [hereinafter JACOB'S NEW LAW DICTIONARY, collectively].

242. A.W.B. SimpSON, ED., BIOGRAPHICAL DictionaRY OF THE COMMON LAW 272 (1984); Again, Justice Thomas used two separate editions of this dictionary in Lopez and Hubbell. See supra note 218 .

243. McDowell, supra note 218 , at 260-61. In addition to the NEW LAW DICTIONARY, Jacob published 33 legal texts (many multi-volume). 
legal lexicon. ${ }^{244}$ Jacob's New Law Dictionary may be difficult for commentators to interpret now, but in the early republic it was "the most widely used English law dictionary." 245 Near the turn of the century, various American Supreme Courts cited Jacob's New Law Dictionary, and like Cunningham's Law Dictionary, Jacob's is more than a compilation of words with definitions; it is "a dictionary, an abridgement, and a vocabulary." 246 For Jacob, it was not enough to simply define words, "he strove to put the meaning in context."247

Like Cunningham, Jacob includes the restriction against holding "office," but unlike Cunningham, who included this subject only under "Foreigner," Jacob places it under "foreigner" and "alien": "And persons that are aliens, or born out of the realm, are incapable to be members of parliament, enjoy offices, $\& r . " 248$ Under the definition for "foreigner," Jacob repeats this idea (almost verbatim to Cunningham's definition, but different from his own "alien" definition), again indicating a difference between "alien" and "foreigner," in that they require separately defined and different restrictions. 249

In addition to distinguishing "alien or foreigner" under "enemy" as does Cunningham, Jacob also includes this idea under "alien": A foreigner taken in battle "shall suffer death by the martial law, and not be indicted at the Common law." But "Aliens, living under the protection of the king, may have the benefit of a general pardon." 250 Jacob supplies a reason for this differentiation: the "foreigner" was "never in the protection of the king." 251 Again, residency is paramount.

Like Cunningham, Jacob does not refer to foreign-born or foreign citizens or subjects located extraterritorially as "aliens." For example, under "foreign kingdom," Jacob describes a hypothetical situation where an individual from "Holland, or any foreign kingdom" purchases goods from an English sub-

244. HOLDSWORTH, supra note 221 , at 175-78. Jacob's and Cunningham's law dictionaries were the most popular current works at the end of the eighteenth century, with COWELL'S INTERPRETER (infra note 254) ranked second, but designated as one of many "[e]arlier dictionaries still in widespread [use]," not as a current text. Id at 132, 175-78; See, McDowell, supra note 218, at 266 (finding that JACOB'S NEW LAW DICTIONARY "surpassed" in quality the works of, inter alia, Cowell, Blount and even Rastell).

245. Id.; Leonard Levy, Origins of the Fifth Amendment and its Critics, 19 CARDOzo L. REv. 821,854 (1997).

246. 12 HOLDSWORTH, supra note 224 , at 176.

247. McDowell, supra note 218, at 277.

248. JACOB'S NEW LAW DICTIONARY, supra note 244, at title "foreigner."

249. Under "foreigner," the individual is specifically denied admission to the Privy Council, where under "alien" the individual is denied admission to "offices." This most likely indicates the same restriction. See id.; and see 2 CUNNINGHAM, CUNNINGHAM's LAW DictionaRY, title "foreigner." Note that Jacob includes an alien's right to sue for defamation, "assault and battery," and the restriction against "bringing any real action." He adds that an "alien" can sue an English subject regarding the alien's "house of necessary habitation, being for the benefit of trade."

250. JACOB, JACOB'S NEW LAW DICTIONARY at title "alien."

251. Id. 
ject and then returns to the individual's country without paying. Jacob refers to this extraterritorial individual as a "stranger." 252

Like Blackstone, Viner and Cunningham, Jacob defines an "alien" as an individual who: 1) is foreign-born, and 2) resides in a sovereign's territory other than the one where he was born, and under that sovereign's protection. Jacob does not refer to individuals located extraterritorially as "aliens," and makes the explicit distinction between "alien or foreigner." 253 Jacob is even clearer than Cunningham on this point because he repeats the differentiation under "alien," where Cunningham only makes the point under the collateral "enemy" definition.

\section{Cowell's Interpreter}

Cowell's Interpreter does not clearly differentiate between "alien" and "foreigner," and is only somewhat in line with the preceding definitions of "alien." 254 This work was a popular legal dictionary in the late eighteenth century, ${ }^{255}$ but was rarely cited by American Supreme Courts at the time. ${ }^{256}$ Although John Adams had multiple editions in his personal collection, ${ }^{257}$ no reference to the work was found in the contemporaneous House and Senate Journals, or the various Documentary Histories. This may be because the Interpreter was compiled in the early seventeenth century, not, as the works previously detailed, in the mid to late eighteenth century, or because it devoted a lot of space to defining irrelevant civil law terms and espousing Cowell's political agenda.

First published in 1607, the Interpreter provides definitions of English legal terms and similar terms from the civil law. Cowell was a prolific writer and the Interpreter was his most famous-and most controversial-publication. The controversy arose because Cowell defines terms to reflect his theory of royal absolutism: for example, Cowell defines a king as having absolute power above the law, with Parliament serving the monarchy. ${ }^{258}$ Consequently, the book caused an uproar in the Parliament of 1610, causing James I to summon Cowell before the Privy Council and suppress the book by proclamationclaiming that it was "in some poynts very derogatory to the supreme power of this crowne: in other cases mistaking the true state of the parliament of this

252. Id. at title "foreign kingdom."

253. Id.

254. JOHN COWELL, THE INTERPRETER OF WORDS AND TERMS, title "Alien" (unpaginated) (1701) [hereinafter INTERPRETER].

255. McDowell, supra note 218 , at 261.

256. See, e.g., Fairfax's Devisee v. Hunter's Lessee, 11 U.S. 603 (1815); Fulgham v. Lightfoot, 5 Va. 250 (Va. 1798); Respublica v. Roberts, 1 Yeates 6 (Pa. 1791).

257. Adams's Library collection, available at http://www.johnadamslibrary.org/search/books/? author= cowell.

258. Id. 
Kingdome . . . and speaking unreverently of the Common Law of England."259 Despite this suppression, the book apparently had utility and was reprinted in England eleven times during the seventeenth and early eighteenth centuries. ${ }^{260}$

However, Cowell's style drove others to publish their own updated lexicons. In the preface to Thomas Blount's Nomo-Lexicon, Blount pointed out why he felt his dictionary was necessary: Cowell "is sometimes too prolix in the derivation of a Word, setting down several Authors [sic] Opinions, without categorically determining which is the tru[th]."261

Cowell's definition of "alien" is not influenced by his royal absolutism, and is short and familiar: "Alien ... signifies one born in a strange Country: It is usually taken for the contrary to a Denizen, or Natural Subject; that is, one born in a strange Country, and never here infranchised [sic]."262 This was adopted almost verbatim by Cunningham, who, unlike Cowell, cites Calvin's Case as the source. ${ }^{263}$ Cowell's following sentence simply repeats what Jacob details regarding individuals born extraterritorially who are not to be considered "alien" since they were at that time still under the king's obedience. Furthermore, the last sentence is also repeated by Viner, Cunningham, Jacob and Blackstone: "if one born out of the King's allegiance, come and dwell in England, his Children begotten here, are not Alien, but Denizens." The inference here is that the father is an "alien," not a "foreigner," and therefore his issue deserve protection.

Unlike the previous examples, especially Jacob's and Cunningham's, Cowell's context does not help much. By defining an "alien" as an individual born in a "strange country," without contextualizing with details regarding personal rights and the various restrictions imposed due to residence in the sovereign's realm, this definition could mean anyone born somewhere "strange," including those located extraterritorially. But like Cunningham's, Cowell's "alien" is located within the king's dominions, because in addition to being foreign-born, the "alien" must also not be enfranchised "here"; and as "contrary" to a denizen and natural-born subject, Cowell's definition reflects Blackstone's. But this requires inferences and even knowledge of who "the People" are, as detailed by Blackstone years later. Cowell is prolix and confusing. Cowell does not define "foreigner" or "foreign." 264 He does supply a similar definition for "foreign attachments" as Cunningham, but again, without con-

259. Stuart Royal Proclamations 1.244 (J. F. Larkin and P. L. Hughes, eds. 1973); G. E. Aylmer, The Meaning and Definition of "Property" in Seventeenth-Century England, 86 PAST AND PRESENT 87, 88-89 (1980).

260. Brian P. Levack, Cowell, John (1554-16l1), OXford Dictionary OF NATIONAL BIOGRAPHY, Oxford University Press (2004) available at http://www.oxforddnb.com/view/article/ 6490 (last visited 7 April 2007).

261. Thomas Blount, Nomo-LeXicon: A Law Dictionary at "Preface" (2nd ed. 1691) [hereinafter NOMO-LEXICON].

262. COWELL, supra note 254, at title "Alien."

263. I CUNNINGHAM, CUNNINGHAM's LAW Dictionary, title "Alien."

264. Cowell does not define "Enemy" either. 
text. 265 Consequently, Cowell's use of "foreigner" here only infers that the "foreigner" cannot be located, not that the individual may be located extraterritorially. ${ }^{266}$ Without making substantial inferences, and in contrast to the other available definitions, Cowell's definition of "alien" is incomplete in its generality, and on its own was not likely helpful to the drafters. ${ }^{267}$

\section{Bacon's Abridgment}

A popular eighteenth century legal abridgement that also does not consistently track Blackstone, Viner, Cunningham, and Jacob is Matthew Bacon's, $A$ New Abridgment of the Law, first published in $1736 .{ }^{268}$ Bacon does not detail "foreign," "foreigner," or "enemy," and inconsistently and confusingly uses both "alien" and "foreigner" to describe individuals located extraterritorially. ${ }^{269}$ Unlike the other authors, little is known about Bacon, other than he was not a prolific legal writer. ${ }^{270}$ In 1821 Jefferson recommended that all lawyers should read Bacon's Abridgment before Blackstone's Commentaries, specifically to

265. COWELL, supra note 254, at titles "Alien," "Foreign Attachments"; 2 CUNNINGHAM, CUNNINGHAM's LaW DictionaRY, title "Foreign Attachments."

266. See id.

267. Henry Finch, Cowell's contemporary, also used "alien" generally, but in context it tracks with Blackstone et al. SIR HENRY FINCH, LAW: OR, A DISCOURSE THEREOF IN FOURE BOOKS 176179 (1636). In Chapter 17 of Finch's work, which exclusively addresses rights within the realm, Finch writes: "[A]n Alien borne in amitie may have propertie in goods, and buy and sell, and their bargaines good: and may also bring personall Actions." Id. at 178. Like Cowell, Finch did not discuss "foreigner," "enemy," or "stranger." Id . at title "Index" (unpaginated). Another contemporaneous source does not address "alien" or "foreigner": PETER S. DU PONCEAU, A DISSERTATION ON THE NATURE AND EXTENT OF THE JURISDICTION OF THE COURTS OF THE UNITED STATES, BEING A VALEDICTORY ADDRESS DELIVERED TO THE STUDENTS OF THE LAW ACADEMY OF PHILADELPHIA, AT THE CLOSE OF THE ACADEMICAL YEAR, ON THE 22D APRIL, 1824 xxxii (1824).

268. 1-4 MATTHEW BACON, A NEW ABRidgMENT OF THE LAW, ALPHABETICALly Digested UNDER PROPER TITLES ( $1^{\text {st }}$ American from $6^{\text {th }}$ London ed. 1813) [hereinafter BACON'S ABRIDGMENT]; See HERBERT JOHNSON, IMPORTED EIGHTEENTH-CENTURY LAW TREATISES IN AMERICAN LIBRARIES, 1700-1799 at 5 (1978). Unlike VINER'S ABRIDGEMENT, Bacon's did not consist of notes of cases and statutes put together under alphabetical heads, but foreshadowed modern legal encyclopedias in containing a collection of treatises on all branches of the law; in this way it was superior to Viner's work, and attained a popularity which Viner's was unable to match. N. G. Jones, Bacon, Mathew, OXFORD DictionARY OF NATIONAL BIOGRAPHY (2004), available at http://www.oxforddnb.com/view/article/64033 (last visited March 30, 2007). Charles Viner refused to regard BACON'S ABRIDGEMENT as an abridgement at all, but just "called so in order to make it more saleable." Id.

269. 2 BACON, BACON'S ABRIDGMENT; 1 BACON, BACON'S ABRIDGMENT (both volumes reflect information from the $3 \mathrm{~d}$ edition, but commentary regarding the American Revolution is added in the later edition); 1 BACON, BACON'S ABRIDGMENT (3d ed. 1768).

270. In 1731 Bacon anonymously published the COMPLEAT ARBITRATOR: OR, THE LAW OF AWARDS AND ARBITRAMENTS, which reached a third edition in 1770 . In 1736 (also published anonymously) the first two volumes of BACON'S ABRIDGMENT appeared, the third volume following in 1740. Only the first two thirds of the fourth volume were completed by Bacon before his death. N. G. Jones, supra note 268. 
understand how English law evolved from Bacon to Blackstone. ${ }^{27 l}$ And although Professor Goebel concludes that "a lot of American law came out of Bacon's . . A Abridgment[]," it was not recommended as a valid source for definitions, but only as a source of contrast. ${ }^{272}$

Nonetheless, numerous American Supreme Courts cited to Bacon's Abridgment, ${ }^{273}$ and many colonial and Presidential libraries kept it on their shelves. ${ }^{274}$ But this abridgment is more confusingly worded and organized than any of the other lexicons, and is not mentioned in any House or Senate Journal-and along with Cowell's Interpreter-Madison did not recommend it be used by the Continental Congress. ${ }^{275}$

Unlike the more organized dictionaries and abridgements, Bacon discusses "alien" by only defining who is not considered an alien. ${ }^{276}$ Although this section is entitled, "Who are Aliens ...," Bacon begins with "[a]ll those are natural-born subjects whose parents, at the time of their birth, were under the actual obedience of our king, and whose place of birth was within his dominions." 277 The following four pages - the remainder of this initial section-continue in this vein by further defining "natural-born subject," supplying familiar examples also cited by Blackstone, Viner, et al. ${ }^{278}$ Bacon rarely uses the noun "alien" here, and points out that issue born of foreign "enemies" while residing within the realm are not statutorily considered "natural-born subjects," because these issue were not "born . . . under the protection of the king." 279

Like Jacob and others, Bacon supplies the example of an "alien" merchant who takes "a lease of a house for his habitation"- similarly using residence to explain that if the alien "depart the kingdom, or die, [the lease] goes to the king." 280 But unlike the other lexicons, instead of using "foreigner" or "stranger," or simply not using "alien," to describe an individual residing extraterritorially, Bacon specifically writes: "The property of an alien, resident abroad ..." and, "if an alien, resident abroad, dies intestate, his whole [personal] property here is distributable according to the laws of the country where

271. JefFerson Cyclopedia, A COMPREhENSIVE Collection of the Views of Thomas JEFFERSON 488 (John P. Foley, ed., 1900) [§ 4545: Lawyers, Education of] (not indicating how contrasting Bacon with Blackstone shows legal change).

272. Goebel, supra note 197 , at 455

273. See, e.g., Glass v. Sloop Betsey, 3 U.S. 6 (1794); Grier v. Grier 1 U.S. 173 (Pa. 1786); Eppes v. Demoville, 6 Va. 22 (Va. 1799); Franklin v. Executors of Camp, 1 N.J.L. 227 (N.J. 1793).

274. JOHNSON, supra note 268, at 59; Adams's Library collection, available at http://www.johnadamslibrary.org/search/books/?author=bacon.

275. 24 Journals of the Continental Congress 89.

276. 1 BACON, BACON'S ABRIDGMENT, at 125-26.

277. Id. at 125 .

278. See id. at 126-29. Like Viner, Bacon pointed out that "suing is but a consequential right of ... protection." Id. at 139; VINER, VINER's ABRIDGEMENT at 273, § 15.

279. BACON, BACON'S ABRIDGEMENT 126.

280. Id. at 134. 
he so resided."281 By using "resident abroad," Bacon ignores his own use and other definitions of "the king's dominion," which arguably extend abroad. ${ }^{282}$

Bacon also uses the phrase "resident alien" in relation to an "alien's" rights within the realm:

A resident alien, it hath been adjudged, is entitled to the benefit of a general pardon; but, if he is not in the kingdom at the time of the promulgation of the pardon, he is not within the benefit of it, for he is no [sic] otherwise a subject, but by his residence here. 283

Bacon does not explain how the individual can be both an "alien" and a "subject." In fact, he took pains to indicate the difference in the section entitled "Of Naturalization and Denization, the Difference and Effect of them."284 Bacon also does not indicate how this individual can be considered a "resident alien" when not residing within the realm. ${ }^{285}$

Bacon's use of "foreigner" throughout his abridgement is similarly confusing. He does supply the same example as Cunningham and others regarding the restriction on subjects who travel extraterritorially to teach their respective trades to "foreigners," using "foreigner" here to describe foreign citizens or subjects residing extraterritorially. ${ }^{286}$ But only a few pages later Bacon uses "foreigner" to describe a foreign citizen or subject who "has established himself and family in Great Britain."287 Similarly, under his definition of "Costs," Bacon uses "foreigner" regarding an individual who may "reside in this country."288 However, under "Bail in Civil Causes," Bacon uses "foreigner" to describe an individual "sued here on a contract made in his own country with a fellow subject," and more specifically, as an individual who "resides abroad."289

This may only be confusing in relation to the other lexicons' definitions. Taken on its own, Bacon's uses of "foreigner" could infer a general definition of "foreigner" that includes "alien," but considering one of his uses of "alien," as an individual residing "abroad," this just becomes more confusing. But by using "alien, resident abroad" and "resident alien," Bacon does imply that there is dif-

281. Id. at 137 (emphases added). This is the only use of "resident alien" I encountered in 18th century lexicons. It did not have a definition like it does today. See The Oxford Dictionary of Law 23.

282. See, e.g., id. at 126 (stating that "[i]f one of the king's ambassadors in a foreign country hath issue there by his wife, being an English woman, by the common law they are natural bom subjects").

283. Id.

284. See id. at 129-32.

285. Although inferences can be made; $1 d$. at 137.

286. Id. at 128 (stating that "if any manufacturer or artificer ... go into any country out of his majesty's dominions, there to use or exercise, or teach any of the said trades or manufactories to foreigners. . [ [he] shall not return within this realm within six months.").

287. Id. at 131 .

288. 2 BACON, BACON'S ABRIDGMENT at 57.

289. 1 BACON, BACON'S ABRIDGMENT at 331, 504 (emphasis added). 
ference from an alien residing here. That is, these qualifiers used in conjunction with "alien" indicate that "alien" used on its own refers to a foreign-born individual located within the realm.

\section{Tomlins's Law of Wills}

Unlike Bacon, Sir Thomas E. Tomlins's uses of "alien" and "foreigner" in this popular work indicate a consistent distinction between the terms. ${ }^{290}$ In the late eighteenth century, Tomlins was a writer, newspaper editor, and lawyer before being appointed counsel to the chief secretary for Ireland. ${ }^{291}$ Tomlins was a prolific writer, but he was best known for being the editor of Jacob's Law Dictionary, beginning in 1797 and producing further editions under his own name until 1838.292 Tomlins's best known personal work, A Familiar Explanation of the Law of Wills, was promoted as "a clear account of the subject for the layman."293

In Chapter II, entitled "Who May Make Wills, And Who Are By Law Prevented From So Doing," Tomlins defines "Alien" in a parenthetical as: "one born out of the King's dominions, and whose father was not a British subject." 294 This concise version of Cowell's Coke interpretation is then qualified and contextualized by Tomlins: "while living under the English government" and, "under the idea that he [that is, an "alien"] has the King's license for staying in the kingdom, and is therefore in some degree entitled to the protection and privilege of a subject."295 The passage goes on, detailing the same property rights seen in Blackstone, Viner, Cunningham, and, of course, Jacob. ${ }^{296}$

In the following paragraph, Tomlins switches the discussion from "alien" in his previous paragraph to "foreigner," clearly distinguishing the terms: ${ }^{297}$

As to the case of a foreigner having money in the stocks, or other personal property in the kingdom; if he has what is in law termed his domicil in a foreign country, that is, if he is resident there, or only occasionally absent therefrom, and is subject to its laws, the disposition of such property, either under his Will, or in the case he dies without a Will, shall be regulated by the laws of the country of which

290. SiR THOMAS E. TOMLINS, A FAMILIAR EXPLANATION OF THE LAW OF WILLS: THE LAW OF DESCENT AND DISTRIBUTION, IN CASE NO WILL, IS MADE: AND THE OFFICE AND DUTY OF EXECUTORS AND ADMINISTRATORS: WITH FORMS OF WILLS, AND OTHER PRACTICAL INSTRUCTIONS 16-18 (1785) [hereinafter LAW OF WILLS].

291. 57 Dictionary OF NATIONAL BIOGRAPHY 17 (Sidney Lee, ed.1899).

292. Id.

293. No citations for this could be located in the various American Supreme Courts, nor in the House and Senate Journals.

294. TOMLINS, LAW OF WILLS, supra note 290 , at 16 . Contrast the specificity here with Bacon's confusing definitions.

295. Id.

296. See id.

297. These are the only times Tomlins uses "foreigner" and "alien" in the entire 199 pages. 
he is a subject; but if he is domiciled in England, then by the English laws. 298

Tomlins is careful not to refer to the individual residing extraterritorially as an "alien," explicitly changing the subject of the previous paragraph: "As to the case of a foreigner." 299 He then refers to residency as an indication of personal rights within the realm, and if the "foreigner" is not "domiciled" extraterritorially, his legal rights to devise are those Tomlins details under his discussion of "alien" in the previous paragraph-governed by English law, not the other sovereign's. ${ }^{300}$ Here, a "foreigner" residing locally at his death would not be considered an "alien" if his "domicil" was extraterritorial. Residency, again, is key.

Therefore, according to Tomlins, similar to Blackstone, Viner, Cunningham, and Jacob, an "alien" is an individual who: 1) is foreign-born, and 2) resides in a sovereign's territory other than the one where he was born. Like Cunningham and Jacob, Tomlins's use of "foreigner" fits into Viner's and Blackstone's definitions: A "foreigner": 1) could have all the aforementioned characteristics of an "alien," or 2) is any foreign-born or foreign citizen or subject "domiciled" extraterritorially or locally on a temporary basis.

\section{Burn's New Law Dictionary}

Similarly, Richard Burn's A New Law Dictionary basically regurgitates Jacob, Cunningham and Blackstone. ${ }^{301}$ Although not published until 1792, and some modern commentators have characterized this work as "of little value,"302 this two volume set is informative because it reflects Richard Burn's concise understanding of terms as defined in his very popular and highly respected previous works, published during the relevant period between 1755 and 1789. 303 Blackstone added a note to his Commentaries declaring that Burn's

298. Id. at 17.

299. Id.

300. For a confused discussion of this same topic, see 1 BACON, BACON'S ABRIDGMENT at 137.

301. RICHARD BURN AND JOHN BURN, A NEW LAW DICTIONARY: INTENDED FOR GENERAL USE, AS Well as for GENTLEMEN OF THE PROFESSION (1792) [hereinafter BuRN'S NEW LAW DICTIONARY].

302. OXFORD DictionARY OF NATIONAL BIOGRAPHY, Oxford University Press (2004) available at http://www.ox forddnb.com/public/index.html?url=\%2Findex.jsp.

303. Burn published A DIGEST OF THE MILITIA LAWS, which explained all phases of the new Militia Act of 1757 (30 Geo. II c.25); ECCLESIASTICAL LAW (2 vols.), which like Bum's JUSTICES' MANUAL was a great success, presenting the law relevant to matters arising in ecclesiastical courts; A History of the PoOR Laws (1764); SERMONS ON PRACTICAl SUBJeCtS (4 vols., 1776), and; in 1777 , in collaboration with Joseph Nicolson, Bum published THE HISTORY AND ANTIQUITIES OF THE COUNTIES OF WESTMORLAND AND CUMBERLAND ( 2 vols.), a work based in part on the collections made by Dr. William Nicolson, bishop of Carlisle. In 1783 Burn published a new and ninth edition of Blackstone's COMMENTARIES (4 vols.), and subsequently produced the tenth and eleventh editions. Norma Landau, Burn, Richard (1709-1785), in OXFORD DICTIONARY OF NATIONAL BIOGRAPHY, supra note 307. Interestingly, Burn never intended to publish this "dictionary"; it was basically his personal compilation of terms for use in his writing (published posthumously by his son John Burn). J.G. MARVIN, LEGAL BIOGRAPHY 163 (1847). 
The Justice of the Peace and Parish Officer, ${ }^{304}$ published in 1755, was "collected with great care and accuracy, and disposed in a most clear and judicious method." 305 References to Burn's New Law Dictionary could not be located in contemporaneous American Supreme Courts, but these Courts made countless references to the author's Ecclesiastical Law and Justices' Manual-two works that are much more verbose but reflect substantially similar definitions and uses. ${ }^{306}$

The beginning of Burn's definition of "alien" is very familiar by now: "one that is born out of the dominions of the crown of England." 307 He cites Blackstone for this, and for the discussions of personal rights that comprise the following sections. ${ }^{308}$ These familiar discussions also set the context for an individual's rights under the protection of the sovereign. ${ }^{309}$ Like Jacob and Cunningham, the context is consistent, and unlike Bacon, Burn never refers to an individual located extraterritorially as an "alien." 310 In fact, although John Burn claimed that his father's compilation was entirely original, ${ }^{311}$ it is too similar to Jacob's and Cunningham's to be a mere coincidence, as further evidenced by the corresponding supporting citations. ${ }^{312}$

In any case, Burn's definition tracks Blackstone, Jacob, Cunningham (verbatim in some instances), as well as Viner and Tomlins: an "alien" is an individual who: 1) is foreign-born, and 2) resides in a sovereign's territory other than the one where he was born. Like Cunningham and Jacob, Burn's use of "foreigner" fits into Viner's and Blackstone's definitions: A "foreigner": 1) could have all the aforementioned characteristics of an "alien," or 2) is any foreign-born or foreign citizen or subject located extraterritorially. Again, this is an example of yet another eighteenth century source that differentiates between the terms "foreigner" and "alien."

304. Burn's definition of "alien" in the first volume of this set is considerably more detailed than the definition in his "dictionary," but tracks it nonetheless. See, 1 BURN'S JUSTICE OF THE PEACE AND PARISH OFFICER 148-54, 175, 191 (Thomas Chitty ed., 29th ed. 1845).

305. 1 Blackstone, COMMENTARIES *346.

306. See, e.g., Georgia v. Brailsford, 3 U.S. 1 (Ga. 1794); Upper Alloways Creek v. Elsingborough, 1 N.J.L. 445 (N.J. 1795); Respublica v. Cobbet, 3 Yeates 93 (Pa. 1800); Overseers of Poor v. Over-seers of Poor, 2 Yeates 164 (Pa. 1796).

307. BURN, supra note 307 , at title "Alien," $§ 1$.

308. Id.

309. Id. at $\S \S 2-7,9,10$.

310. Id. at $\S \S 1-12$. Burn did not define "Enemy," and his definition of "Foreigners" is as unhelpful as Jacob's and Cunningham's; but also note that Burn combines the slight difference of those two definitions in his: "though made denizens, or naturalized here, are disabled to bear offices in the government, or to be of the privy council, or members of parliament."

311. See RICHARD BURN, BURN'S NEW LAW DICTIONARY, WITH AN INTRODUCTION BY BRYAN A. GARNER v (2003).

312. Id. at $\mathrm{i}$. 


\section{Rastell's Termes de la Ley}

A relevant legal lexicon that predates even Cowell's 1607 work does put "alien" in context similar to the late eighteenth century writers: John Rastell's The Expocisions of the Terms of the Laws of England, known to most eighteenth century readers as Les Termes de la Ley. ${ }^{313}$ This was the original English legal lexicon, "not derived from older texts," 314 and was still widely used in the late eighteenth century. ${ }^{315}$ Prior to Termes de la Ley, English lawyers studied law in Latin and law-French, mostly from the cumbersome Graunde Abridgements, but because law-French was not widely taught, the law was difficult to understand for both professionals and laymen. ${ }^{316}$ As he stated in the preface, Rastell's goal was to help everyone understand the law. ${ }^{317}$ Rastell's lexicon had entries in two parallel columns, the left in law-French, the right in "black-letter" English. Various editors of this work adjusted Rastell's definitions, but remained true to his core interpretations through the relevant edition published in $1742 .{ }^{318}$ Consequently, Rastell's Termes de la Ley is important because it appears to be the father of all the legal lexicons that followed. ${ }^{319}$

Context was important to Rastell: "Words were important, in his mind, for the power of the things they denote." 320 In a previous abridgment compiled by Rastell in 1519, "[n]owhere is there an explanation that an alien is a foreigner." 321 Rastell briefly explained that "alyens" should not be allowed to "discouer the secretes of the realme," or to own property without the "kynges lycence." 322 He then introduces what later becomes a familiar restriction (governed by residency) detailed by later lexicographers, including Bacon, that the king "shall haue the possessions" of aliens if those individuals do not continue

313. John Rastell, THE EXPOCisions of the Terms of the LaWS OF ENGLAND (1567). Note that Rastell first published this lexicon as EXPOSICIONES TERMINORUM LEGUME ANGLORUM in 1523 or 1524. Ian Lancashire, Law and Early Modern English Lexicons, in Selected Proceedings of the 2005 Symposium on New Approaches in English Historical Lexis (HEL-LEX) 8-23 (R. W. McConchie et al, eds. 2006), available at http://www.lingref.com/cpp/hel-lex/2005/paper1342.pdf (last visited March 2, 2009).

314. II JOHN SPELMAN, THE REPORTS OF SIR JOHN SPELMAN 185 (1978).

315. HOLDSWORTH, supra note 224 , at 175-78.

316. Id.

317. See RASTELL, supra note 307 , at "Preface".

318. This was the $30^{\text {th }}$ and last edition published prior to 1789 . Lancashire, supra note 320 , at 10.

319. See generally Howard Jay Graham, The Rastells and the Printed English Law Book of the Renaissance, 47 LAW LIBRARY JOURNAL 22 (1954). Rastell's work has been considered important by various commentators because of its influence on eighteenth century legal writers. Even Rastell's latest eighteenth century edition predates the other contemporary lexicons. Note that it was not mentioned in any of the House or Senate Journals, or cited by the various and contemporaneous federal and State courts until 1815.

320. Lancashire, supra note 320 , at 13

321. Id.; see RASTELL, supra note 307.

322. See RASTELL, supra note 307, at title "Alyens." 
to inhabit the realm. ${ }^{323}$ Unlike Bacon, Rastell and his editors did not use "alien" here when referring to an individual located extraterritorially.

In the 1685 Termes de la Ley, this heavily edited edition explains "alien" as briefly as Cowell, but in context similar to Jacob and Cunningham-who were apparently influenced by this work:

Alien is a Subject born out of the liegeance of our King, and he cannot have any real or personal Action concerning land, but in every such Action the Tenant or Defendant may plead that he was born in such a place, which is not within the Kings liegeance, and demand judgment if he shall be answered. ${ }^{324}$

Rastell establishes the context with the individuals' property rights within the realm, then continues by detailing "inheritance within England" in the following and penultimate paragraph. He ends his "alien" section by giving the same reasons Cunningham did for these restrictions: " 1 . The Secrets of the Realm may by this be discovered; 2 . The Revenues of the Realm shall be taken and injoyed by Strangers born." 325

Although Rastell does not define "foreigner," like Cowell he does cover "Forrein Attachment" under the title "Forrein": 326 "an Attachment of the Goods of Forreiners within any Liberty or City, for the satisfaction of any Citizen to whom the said Forreiner owes money."327 Unlike Cowell, but in the same manner as Cunningham, Rastell establishes the context of an alien's rights within the realm, and by specifically using "forreiner" here instead of "alien," he not only establishes a difference between the terms, it can be inferred that the "forreiner" is not located anywhere in the king's realm, because an attachment is necessary in that individual's absence from the relevant jurisdiction. ${ }^{328}$

Therefore, according to Rastell, similar to Blackstone, Viner, Burn, Tomlins, and the two most popular legal lexicons of the time-Cunningham's and Jacob's-an "alien" is an individual who: 1) is foreign-born, and 2) resides in a sovereign's territory other than that of his birth. Rastell does not mention this as a right due to a contract for the sovereign's protection, but residency is nonetheless key. Like Tomlins, Cunningham, and Jacob, Rastell's rare use of "forreiner" fits into Viner's and Blackstone's general definitions: any foreignborn or foreign citizen or subject located extraterritorially.

\section{Justinian's Institutes}

When Thomas Jefferson placed Blackstone's Commentaries alongside

323. Id.

324. See RASTELL, supra note 307, at title "Alyens"(Note that this is repeated under titles "Capacity" and "Disability)."

325. Id.

326. But, oddly, he does not define "forrein."

327. Id. at title "Forrein."

328. Id. 
Justinian's Institutes, he was referring to an even older legal lexicon than Rastell's Termes de la Ley. ${ }^{329}$ Madison recommended that the Continental Congress procure a copy of this ancient work along with the Commentaries and Cunningham's Law Dictionary, ${ }^{330}$ but not likely for its value in defining contemporary legal terms. The Institutes were not cited for definitions in any American Supreme Courts, nor did the Senate or House refer to it.

Justinian's Institutes does not define or even mention "alien" or "foreigner," although the freedmen / free-born and slaves differentiation (and independent / dependant persons discussion) could be the origins of "the People" later detailed by writers from Rastell to Blackstone (and Hamilton). ${ }^{331}$ Thus, the inferences that would be required for eighteenth century readers to glean an understanding of "alien" or "foreigner" are too circumstantial for this work to be useful here.

\section{Blount's Nomo-Lexicon}

However, Thomas Blount, an editor of late seventeenth century editions of Rastell's work, produced a lexicon that is very useful. Blount first produced his own legal dictionary, Nomo-Lexicon, in $1670 .{ }^{332}$ Like Rastell, Blount distinguishes between "alien" and "foreigner," and clarifies that an "alien" is in fact a "foreigner," but one who resides in a country other than where he was born. ${ }^{333}$

Blount found severe defects with the dictionaries of Cowell and Rastell, so he took it upon himself to publish what would be a significant improvement; one that relied more heavily on common law than on civil law (a tradition perpetuated by Cowell). ${ }^{334}$ In his preface, Blount points out why he felt his dictionary was necessary: Cowell was "too prolix in the derivation of a Word," sometimes evading the truth, and Rastell "wrote so long hence, that his very

329. JUSTINIAN'S INSTITUTES was the elementary student textbook which was published by the Byzantine Emperor in 533 A.D. and which was itself largely based, in structure, on the Institutes of Gaius of around 160 A.D.

330. 24 Journals of the Continental Congress 89.

331. JUSTINIAN'S INSTITUTES, TRANSLATED WITH AN INTRODUCTION BY PETER BIRKS \& GRANT MCLEOD, 39-41 (1987); The INSTITUTES does supply some relevant definitions: "Actions: where a man should sue and be sued"; followed by "If people submit themselves and agree to someone's jurisdiction, any judge who is in charge of a seat of judgment or has other jurisdiction has jurisdiction over those agreeing." 1 THE DIGEST OF JUSTINIAN BOOK 5, $\$ 1$ (unpaginated) (Alan Watson, ed. 1998).

332. COWLEY, supra note 147 , at lxxix.

333. See BlouNT, supra note 261 ; see ThOMas BlounT, GlossograPhIA, OR, A Dictionary INTERPRETING THE HARD WORDS OF WHATSOEVER LANGUAGE NOW IN OUR REFINED ENGLISH TONGUE WITH ETYMOLOGIES, DEFINITIONS, AND HISTORICAL OBSERVATIONS ON THE SAME: ALSO THE TERMS OF DIVINITY, LAW, PHYSICK, MUSICK, MATHEMATICS, WAR HERALDRY, AND OTHER ARTS AND SCIENCES EXPLICATED 18 (1681) [hereinafter GLOSSOGRAPHIA].

334. See generally COWLEY, supra note 147. McDowell, supra note 218, at 266. 
Language and manner of expression was almost antiquated."335

With this in mind, as a barrister and a member of the Inner Temple, Blount combined his practical legal experience with his editorial expertise (Blount had produced a popular general dictionary ${ }^{336}$ ) to write a legal work useful "from the Coif to the puny-Clerk." 337 His Nomo-Lexicon quickly superseded its predecessors, and was the first dictionary of its kind to consistently cite references to authorities, statutes, and treatises. ${ }^{338}$ Even over a century later, Blount's law dictionary, A Law-Dictionary and Glossary, was still in widespread use by laymen and lawyers. ${ }^{339}$

Blount does not define "foreigner" in Nomo-Lexicon, but does define "stranger" as "generally a Man born out of the Realm, or unknown," and one who is "not privy" and not a "party."340 Under "Forein Plea" he points out that this type of plea was a matter not of this jurisdiction, and under "Forein Answer," similarly, this answer is not triable in the jurisdiction. The only mention of "foreiner" comes under "Forein Attachment": the definition echoing Rastell et al, inferring that the "foreiner" is located extraterritorially.

Blount's concise definition of "alien" recalls Blackstone's: "One born in a strange Countrey"; and Blount adds, "usually taken for the contrary to Denizen, or a natural subject, that is, a stranger never here enfranchised." 341 The even more concise definition of "alien" in Blount's Glossographia is instructive: "A Forreigner, a Stranger born, and not here enfranchised."342

Therefore, according to Blount, similar to Blackstone, Viner, Burn, Tomlins, Cunningham, Rastell, and Jacob-an "alien" is an individual who: 1) is foreign-born, and 2) resides in a sovereign's territory other than that of his birth. Foreign and "stranger" imply separateness in general, but perhaps Blount's use of the word "Forreigner" in Glossographia is his most relevant contribution to this discussion.

In his first draft of the bill that later became the Judiciary Act of 1789 , Oliver Ellsworth spells "foreigner" exactly like Blount does in Glossographia; that is, "forreigner," with two " $R$ "s and a G. That spelling has not appeared in any other legal or general lexicon, nor has it come up in any contemporary treatises, judicial decisions, correspondences, or writings of any kind. If Ellsworth spellchecked his draft with Blount's Glossographia, then he most likely also un-

335. See Blount, supra note 261.

336. That is, GLOSSOGRAPHIA, supra note 333.

337. Id.

338. Id.; COWLEY, supra note 147 , at lxxxix.

339. HOLDSWORTH, supra note 224, at 132; See THOMAS BLOUNT, A LAW-DictionaRY AND GLOSSARY (3d ed. 1717).

340. NOMO-LEXICON at "Stranger."

341. Id. at "Alien."

342. Blount, supra note 261 , at 18 . Note that Blount did not define "foreign," "foreigner," or "Stranger" in this dictionary. 
derstood Blount's (and therefore Blackstone's et al) definition of "alien," and therefore of "foreigner"; that is, an "alien" is a Forreigner, a Stranger born, and not here enfranchised" (not just a "foreigner"); a Foreigner is: a stranger born, located in or outside the territory of which mention is made. Because Ellsworth was so careful with and protective of his word choice, when the House amended the judicial bill and resubmitted it to the Senate for final approval, Ellsworth would have understood during that special Saturday session that there was a difference between the terms, and that "alien" narrowed "forreigner." Therefore, the line that later became known as the ATS would only be available to foreign-born residents of the United States-"here," waiting to be "enfranchised."

\section{Collateral Legal Abridgments}

The following uses of "alien" and "foreigner" in popular contemporaneous-but collateral-legal abridgements are informative: Charles Pope differentiates between "Whatsoever person . . a alien or stranger"; 343 this is repeated verbatim by Joseph Gabbett. ${ }^{344}$ George Hansard refers to the common law as it stood in the late eighteenth century:

any security ... granted to a foreigner or alien, or any person in trust for him, could be made effectual against such estates for recovering the money lent thereon, and reciting that no foreigner or alien, as the law then stood, could bring or prosecute any suit for the recovery of money in any court of law or equity within his majesty's dominions. ${ }^{345}$

John Reeves continually differentiated between "alien" and "stranger," and "alien" and "foreigner," and reported that as of 1783, "goods so imported in ships the property of foreigners, although British-built, were to pay alien and other duties," implying a clear distinction between the terms. ${ }^{346}$

\section{B. General Dictionary Definitions}

Thomas Blount's Glossographia was the most popular general dictionary for several years during the eighteenth century. ${ }^{347}$ It was an important source for the Oxford English Dictionary, and earned Blount the credit for being "the

343. Charles Pope, A PRACTICAL ABRIDGMeNT OF THE CUSTOM AND EXCISE LAWS, RELATIVE TO THE IMPORT, EXPORT, AND COASTING TRADE OF GREAT BRITAIN AND HER DEPENDENCIES 412 (2d ed. 1814).

344. Joseph Gabbett, a Supplement to the Digested Abridgment, and Comparative VIEW, OF THE STATUTE LAW OF ENGLAND AND IRELAND CONTAINING THE STATUTES OF SIX SESSIONS, TO THE YEAR 1817 353-55 (1818).

345. GEORGE HANSARD, A TREATISE ON THE LAW RELATING TO ALIENS, AND DENIZATION AND NATURALIZATION 46 (1844).

346. JOHN REEVES, THE LAW OF SHIPPING AND NAVIGATION: FROM THE TIME OF EDWARD III TO THE END OF THE YEAR 1806 7, 20, 24, 29, 56, 210 (2d ed. 1807).

347. See COWLEY, supra note 147 , at lxxxix. 
first lexicographer of a purely English dictionary to attempt an etymology of words." 348 But by far the most influential eighteenth century general dictionary was Doctor Johnson's, A Dictionary of the English Language, first published in 1755.349

According to the publishers of the Octavo edition of Johnson's dictionary-a digitally scanned version of the 1755 original-Johnson's dictionary is to English lexicography "what the King James Bible is to the English church." 350 This is well established. But this lexicon was not cited by American Supreme Courts until the nineteenth century, nor was it in use by the Senate or House in the eighteenth century, although it is more than likely eighteenth century readers and writers had access to a copy.

Johnson's general definition of "alien" mirrors the definitions in modern general dictionaries: he initially defines the noun "alien" as "A foreigner," and Johnson elaborates: "A stranger," which he also defines as "A foreigner." 351 But just below this, Johnson shows a use of the word that distinguishes it from "stranger"/"foreigner" in a familiar way: "aliens and strangers."

Then, on the next page, Johnson adds "alien" as defined "In law," as opposed to in general. ${ }^{352}$ Here he summarizes a cogent section of Cowell's Interpreter:

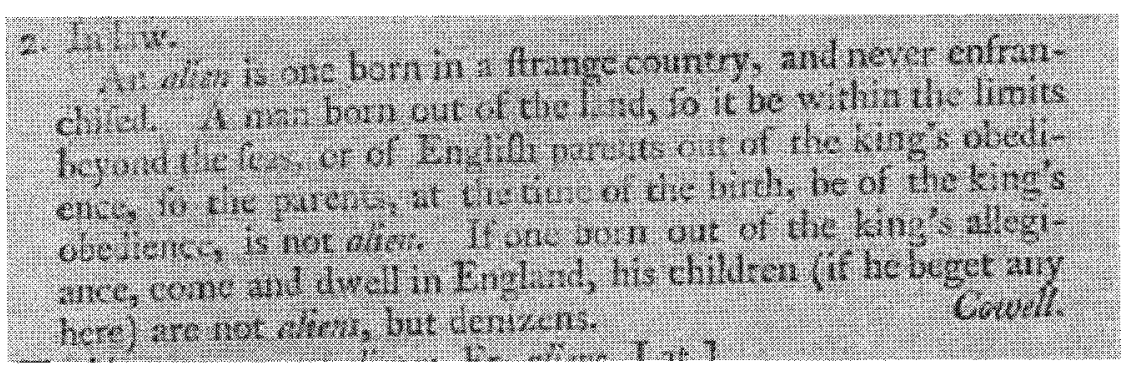

Recall that this definition was also employed by Jacob, Blount, Cunningham, and others. The importance of it here in a general dictionary is twofold: it reached more people, and more importantly, it distinguishes between a general definition of "alien" and a legal definition, succinctly defining the difference in a way, with little inference, that made sense.

348. DEWITt StaRnES AND GERTRUDE NOYES, THE ENGLISH DICTIONARY FROM CAWDREY TO JOHNSON 1604-1755 46 (1991).

349. Noah Webster's A COMPENDIOUS DictionaRY OF THE ENGLISH LANGUAGE did not come out till 1806.

350. See Octavo's introduction to the Johnson project, available at http:/www.octavo.com/ editions/johdct/

351. Samuel Johnson, A Dictionary of the English Language at "Alien" (1755) (Octavo edition).

352. Id. 
To Johnson, an "alien" was simply a "foreigner," but was also distinguished, not only in the "alien and stranger" line, but "In law," as one within the realm and not yet enfranchised. A "foreigner," on the other hand, was a "man that comes from another country; not a native; a stranger." Johnson does not use "alien" to define "foreigner." Thus, Johnson's "alien" can be understood as a subset of "foreigner," an individual residing in a land different from his birth where he had yet to be naturalized.

\section{International Definitions}

Emmerich de Vattel's treatise, The Law of Nations or the Principles of Natural Law, had a "great influence on the American Founding generation." 353 On questions concerning the law of nations, like the ATS, the Framers turned to the well-known French publicist. ${ }^{354}$ Vattel's treatise was first published in English in 1760 and again for the American market in 1775 and 1787.355 James Wilson, John Rutledge, and more importantly, Oliver Ellsworth, cited Vattel during the Constitutional Convention and the ratification debates. ${ }^{356}$

The 1787 translation, with which Ellsworth was familiar, ${ }^{357}$ uses the noun "alien" only one time within the text, but uses "foreigner" over forty times. Because of the nature of Vattel's international discussions, there was no call for him to detail the relations between a foreign-born resident (that is, an "alien") and the State he inhabited. "Foreigner," on the other hand, was used because Vattel's various points related to a State and its dealings with foreign States and their citizens; for example, concerning international trade. ${ }^{358}$ Vattel's translator primarily uses "foreigner" to refer to individuals located extraterritorially. ${ }^{359}$

But in section 112, which deals with the "right of Escheatage," Vattel discusses the rights of a "foreigner" to inherit: "foreigners are excluded from all inheritances in the state, either with respect to the goods of a citizen or to those

353. J. Andrew Kent, Congress's Under-Appreciated Power to Define and Punish Offenses Against the Law of Nations, 85 TEX. L. REV. 843, 851 (2007). Benjamin Franklin notes that "Vattel" was "continually in the hands of the members of our Congress now sitting," as early as 1775. Lee, supra note 5, at 848 (citing, Letter from Benjamin Franklin to Charles Dumas (Dec. 19, 1775), in 2 REVOlUTIONARY DIPLOMATIC CORRESPONDENCE OF THE UNITED STATES 64 (Francis Wharton ed., Washington 1889)).

354. Lee, supra note 5, at 847-48; see John C. YoO, THE POWERS OF WAR AND PEACE: ThE CONSTITUTION AND FOREIGN AFFAIRS AFTER 9/11 32 (2005).

355. Joel R. Paul, The Geopolitical Constitution: Executive Expediency and Executive Agreements, 86 CAL. L. REV. 671, 736 (1998).

356. Id.

357. Abraham C. Weinfeld, What Did the Framers of the Federal Constitution Mean by "Agreements of Compacts?," 3 U. CHI. L. REV. 453, 459 (1935).

358. See E. de Vattel, The law of nations; OR Principles of the law of nature: APPLIED TO THE CONDUCT AND AFFAIRS OF NATIONS AND SOVEREIGNS 68,69 (1787).

359. Id. at $68,69,84,86,245,430$. However, "foreigner" was used to refer to foreign-born individuals located in England. Id. at 167. 
of an alien." 360 This only occurrence of "alien" in the 1787 text, directly contrasted to "foreigner," indicates that "alien" and "foreigner" have different definitions, and that "alien" is narrower than "foreigner." By contrasting "alien" with "citizen" and "foreigner" in the same sentence, Vattel's translator infers that an "alien" is an individual living in a state other than the state of his birth, and that a "foreigner" is not, in this instance, an "alien." 361

Considering that the overwhelming majority of legal dictionaries and treatises, the general dictionaries, and the primary international treatise of the time differentiate between the terms "foreigner" and "alien," the relevant legislators of the late eighteenth century more than likely did as well. To better understand this, an in-depth look at relevant and contemporary writings is necessary.

\section{V. \\ AN UNDERSTANDING OF "ALIEN" AND "FOREIGNER" IN RELEVANT Historical WRITINGS}

By far the term "foreigner" was used more often than "alien" in the eighteenth century. In fact, "alien" was never used in any of the State ratification debates, where "foreigner" was used countless times. ${ }^{362}$ The U.S. Constitution, the Articles of Confederation and none of the State Constitutions used the narrower term, "alien," where the Constitutions of New York, North Carolina, Pennsylvania, Vermont and Virginia used "foreigner" broadly. ${ }^{363}$ Generally, "alien" was used regarding naturalization, and therefore referred to individuals residing in the United States. For example, in the various and voluminous notes taken during the Federal Convention of 1787, "foreigner" was used twenty-six times, but "alien" only once. ${ }^{364}$ The following writings are examples of the consistency with which the terms were used, and provide a possible explanation for the House's change from "foreigner" to "alien" in the Judiciary Act of 1789. That is, the uses are in line with the legal definitions: a "foreigner" is a foreignborn individual located here or extraterritorially, and an "alien" is a foreign-born resident of one of the several states. ${ }^{365}$

360. Id. at 272-73.

361. Hugo Grotius's relevant works were not helpful in defining either "alien" or "foreigner." The latter term was used only once, and the former was mainly used in relation to religion. HuGO GROTIUS, THE ILlUSTRIOUS HUgo GROTIUS OF THE LAW OF WARRE AND PEACE WITH ANNOTATIONS, III PARTS, AND MEMORIALS OF THE AUTHOR'S LIFE AND DEATH $16,17,90,247,253$, $254,258,305,374,430,557,634,640$ (1655).

362. See infra Part V.G.

363. The original State Constitutions of Connecticut, Massachusetts, Delaware, Rhode Island, Georgia, Maryland, New Hampshire, New Jersey and South Carolina did not use the terms "alien" or "foreigner."

364. See, infra Part IV.G.

365. See, infra Parts V.A-G. 


\section{A. The Federalist Papers}

The importance of The Federalist Papers to the drafters of the Judiciary Act of 1789 is undisputed. Aside from pointing out a distinction between "alien" and "foreigner" in The Federalist No. 22, Hamilton, Madison and John Jay used those terms consistently throughout The Federalist Papers. "Foreigner" is used broadly to indicate foreign-born individuals located here or extraterritorially, where "alien" is only used to indicate foreign-born individuals residing in the United States.

In The Federalist No. 80, while discussing the importance of using national tribunals to adjudicate matters that could offend a foreign sovereign, and therefore disturb the "public peace," Hamilton uses the broader noun "foreigner" to refer to individuals who may need to litigate matters that "involve national questions." 366 This could include resident "aliens," but would more likely include influential foreign merchants and debtors located abroad, the sovereigns themselves, or ambassadors (who would not be considered "alien") who wouldbecause of the protection provided to them by their sovereign-be more likely to be involved in matters of national or international concern. ${ }^{367}$ Hamilton made this clearer when he writes that "maritime causes ... generally depend on the laws of nations, and so commonly affect the rights of foreigners." 368 Maritime causes, which exclusively arise at sea, would therefore affect relations with foreign-born individuals located extraterritorially.

Similarly, in The Federalist Nos. 5, 15 and 30, Hamilton and Jay exclusively use "foreigner" when referring to American debts to and commerce with foreign nations.

Hamilton and Madison exclusively use the noun "alien" when discussing naturalization. In The Federalist Nos. 42, 43 and 69, "foreigner" is never used to refer to a foreign-born individual located here, but "alien" is used five times. ${ }^{369}$

Considering The Federalist Papers in its entirety, it distinguishes between the two nouns in No. 22, then consistently uses the terms in line with the definitions detailed in Part IV. To Publius, a "foreigner" is a foreign-born individual located here or extraterritorially, and an "alien" is a foreign-born resident of one of the several states. ${ }^{370}$

366. THE FEDERALIST PAPERS: No. 80, available at http://avalon.law.yale.edu/18th_century/ fed80.asp (last visited March 3, 2009).

367. See id.

368. Id.

369. Madison also used "alien" in THE FEDERALIST No. 14 to describe a citizen's potential fear of becoming such in a sister state, available at http://avalon.law.yale.edu/18th_century/fed80.asp, (last visited March 3, 2009).

370. In fact, Madison used an extremely rare term for the time, "alien resident[]," in THE FEDERALIST No. 43, available at http://avalon.law.yale.edu/18th_century/fed43.asp (last visited March 3, 2009). 


\section{B. The Anti-Federalist Papers}

The Anti-Federalist Papers reflect a similar understanding of "foreigner" as The Federalist Papers. ${ }^{371}$ However, the noun "aliens" was only used twice, in No. 22. Candidus points out that colonial states that chose not to "join the confederacy of commerce and amity, should be considered as aliens," and that Candidus's proposed plan "lays restraints on aliens." 372 The former use is ambiguous, but indicates that the citizens of the colonial states that refuse to join the "confederacy" would be "alien," because they would not be in league with the sovereign United States, although located within its boundaries-a definition not unlike Blackstone's et al. The latter depends on the plan Candidus set out.

Candidus's plan only addresses foreign public debt, "commerce with foreign nations, and among the several states, and with the Indian tribes," and with the States that chose not to join the "confederacy." 373 The only apparent restraint was placed on the latter idea, where "any goods brought from such state into any of the confederated states . . . should be subject to heavy extra duties." 374 Although both Candidus's uses of "aliens" are ambiguous, a reasonable inference is that the use of both terms creates the familiar distinction between "alien" and "foreigner."

\section{Notes on the State of Virginia}

Thomas Jefferson's uses of "alien" and "foreigner" were not ambiguous. In 1784 Jefferson privately published his Notes on the State of Virginia in France, but the work became so popular that additional editions were published in Britain and America in 1787 and $1788 .{ }^{375}$ No American natural history was more influential during the eighteenth century, though the Notes is, as intended, far more than a simple natural history. ${ }^{376}$ At once a description of the land and people of the state and a theoretical discourse on historical, natural, and political systems, the Notes represents Jefferson's conflicted views on the present and future of the new American nation. ${ }^{377}$

Like Publius, Jefferson does not confuse "alien" with "foreigner." While discussing how America would increase its population, Jefferson wrote: "The present desire of America is to produce rapid population by as great impor-

371. See The ANTt-Federalist Papers Nos. 3, 11, 18-20B, 23, 41-43B, 44, 82 (Morton Borden, ed. 1965).

372. Id. at No. 22.

373. Id.

374. Id.

375. Dorothy Medlin, Thomas Jefferson, André Morellet, and the French Version of Notes on the State of Virginia, 35 WM. \& MARY Q. 1, 85-99 (1978). ATS scholars might find it interesting that Jefferson's Notes was written in response to questions submitted to him by Marbois.

376. Id.

377. Id. 
tations of foreigners as possible... [W] could double our numbers in one year by the importation of foreigners." 378

In Jefferson's discussion of diversity jurisdiction, he writes: "If a controversy arise between two foreigners of a nation ... it is decided by the Consul for their State, or, if both parties chuse it, by the ordinary courts of justice. If one of the parties only be such a foreigner, it is triable before the courts of justice of the country." 379

In the former example, the "foreigner" mentioned is located extraterritorially; that is, he has not yet been imported. In the latter example, the "foreigner" could be located here or abroad. However, in the following example, the foreign-born individual could only be located here, because Jefferson discusses the rights of Tories who decided to stay after the Revolution: "By our separation from Great-Britain, British subjects became aliens." 380 He then uses "alien" numerous times in pointing out rights only residents have "[b]y our laws." 381

Jefferson does not use "alien" to describe a foreign-born individual located extraterritorially, but uses the terms in a similar manner as Publius: a "foreigner" was a foreign-born individual located here or extraterritorially, and an "alien" was a foreign-born resident of one of the several states. ${ }^{382}$

\section{Court Opinions}

No useful Federal Court opinions from the relevant period could be located, and only three useful State court cases published between 1776 and 1791 address the nouns "foreigner" and or "alien." Each consists with the previous definitions.

In Bayard \& Wife v. Singleton, the Supreme Court of North Carolina considered whether a British subject residing in North Carolina was allowed to hold lands in that state. 383 The court states that "it is the policy of all Nations and States, that the lands within their government should not be held by foreigners." 384 The court held that because of this widespread policy, "therefore ... by

378. ThOMAS JEFFERSON, NOTES ON THE STATE OF VIRGINIA, Query VIII (1787).

379. Id. at Query XIV.

380. Id.

381. Id. at Query XVI.

382. In a letter to Edmond C. Genet, dated June 17, 1793, Jefferson used "aliens" to refer to individuals "within our Jurisdiction and enjoying the protection of the laws." PAUL LEICESTER, ED., VII THE WORKS OF THOMAS JEFFERSON IN TWELVE VOLUMES, FEDERAL EDITION (1904-5). In contrast, in a letter sent from Paris to James Swann, dated August 4, 1789, Jefferson used "foreigners" to refer to visitors he had while abroad. He did not use "alien," because the visitors were not residents of a country other than their birth-they were French in France, but foreign to Jefferson and Swann. See id. at Vol. VI.

383. 3 N.C. 42,47 (N.C. 1787 ).

384. Id. 
the common law [we have adopted], aliens are incapacitated to hold lands." 385 In other words, the court held that "foreigners" could not hold lands, that an "alien" is a "foreigner," and a British subject residing in North Carolina is an "alien." That is, an "alien" was a narrower subset of "foreigner."

In Apthorp v. Backus, an opinion joined by then Judge Oliver Ellsworth, the Superior Court of Connecticut held that the plaintiff was not an "alien" when her "title to the land in question accrued," because it accrued prior to the Revolution. ${ }^{386}$ The plaintiff had resided in the state as a British subject like everyone else, and "was [therefore] as much a citizen of the now state of Connecticut, as any person at present within it." 387 The plaintiff was now a British subject residing in Jamaica, because she had been evicted from the premises in question prior to the Revolution. 388 She was never an "alien" in the United States.

A collateral issue involves the plaintiff's representation. The dissent argues that the American attorney representing the plaintiff had not made it clear to her that he was representing her. ${ }^{389}$ In pointing this out, the dissent argues that the attorney was "a foreigner and alien, with respect to the [plaintiff]." 390 The argument could be made that the terms were being used interchangeably here and without significance. However, the attorney and his client were 1) foreign to one another in that there were of different nationalities, and 2) arguably "alien" in that they resided in different countries. In any case, the court used both terms, therefore distinguishing them, and as a member of this court, Ellsworth would have recognized this distinction.

Brinley v. Avery, also before the Superior Court of Connecticut, concerned a plaintiff and defendant who were both residents and subjects of Great Britain. ${ }^{391}$ The parties had made a contract in Great Britain, which was also to be executed there. 392 The defendant fled to Connecticut and the plaintiff pursued him there and sued for breach of contract. The court considered both parties "foreigners" when the contract was made, because they were British subjects residing extraterritorially at that time. 393

Thus, none of these cases referred to a foreign-born individual located extraterritorially as an "alien." In fact, only a few years later, the Supreme Court indicated that the term for a citizen or subject of another country who resides in the United States is "alien." 394

385. Id. (emphasis supplied).

386. 1 Kirby 407,413 (Conn. 1788).

387. Id.

388. Id. at 407 .

389. Id. at 418-19.

390. Id. at 419 .

391. 2 Kirby 22 (Conn. 1786).

392. Id.

393. Id.

394. Talbot, 3 U.S. 133. The Court stated that a U.S. citizen who expatriates himself becomes 


\section{E. Other Acts by the First Federal Congress}

In addition to the Judiciary Act of 1789 , the First Federal Congress had many legislative accomplishments: the passage of the Bill of Rights, the enactments establishing the first three executive departments, the creation of a revenue system, the admission of two states into the Union, the approval of the Secretary of the Treasury's plan for funding the foreign, domestic and state Revolutionary War debts, the establishment of a national bank, and the choice of a location for the U.S. capital city. ${ }^{395}$

Of all the various bills and acts written by the first session of this Congress, other than the Judiciary Act of 1789 , none of the documents contain the noun "alien." 396 Only the bills and act establishing the Department of Foreign Affairs used "foreigner," and only once. ${ }^{397}$ The First Federal Congress never used "alien" to refer to individuals located extraterritorially.

When the second session of the First Federal Congress finally did use "alien" in an act, it referred to foreign-born individuals residing here. "An act to establish an uniform Rule of Naturalization," enacted March 26, 1790, began: "Be it enacted ... That any Alien being a free white person, who shall have resided within the limits and under the jurisdiction of the United States for the

not a foreigner, but an "alien." Id. The relevant parties were U.S. citizens who allegedly became French subjects, but remained in the United States. Id.

395. DOCUMENTARY History OF THE FIRST FEDERAL CONGRESS OF THE UNITED STATES OF AMERICA (Charlene Bickford, ed. 2002), available at http://adh.sc.edu (last visited July 20, 2007).

396. See, e.g., An Act for establishing an executive department, to be denominated the department of Foreign Affairs (1789); A Bill to establish an Executive Department, to be denominated the Department of Foreign Affairs (1789); An Act to establish the Treasury Department, (1789); A Bill to establish an Executive Department, to be denominated the Treasury Department, (1789); An Act to establish an executive department, to be denominated The Department of War, (1789); A Biil to establish an Executive Department to be denominated the Department of War, (1789). 4 DHFFC 689-697 (Charlene Bickford, ed., 1994); 6 DOCUMENTARY HISTORY OF THE FIRST FEDERAL CONGRESS OF THE UNITED STATES OF AMERICA 1975-1991, 2028-32 (Charlene Bickford ed., 1986).

397. "Be it enacted by the Senate and House of Representatives of the United States of America, in Congress assembled, That there shall be an Executive department, to be denominated the department of foreign Affairs: and that there shall be a principal Officer therein, to be called the Secretary for the department of foreign Affairs, who shall perform and execute such duties as shall from time to time be enjoined on, or intrusted [sic] to him by the President of the United States, agreeable to the Constitution, relative to correspondences, commissions, or instructions to, or with public Ministers or Consuls from the United States, or to negociations [sic] with public Ministers from foreign States or princes, or to Memorials or other applications from foreign public Ministers, or other foreigners, or to such other Matters respecting foreign Affairs, as the President of the United States shall assign to the said department." An Act for establishing an executive department, to be denominated the department of Foreign Affairs, (1789). See generally, House and Senate Journals; The Notes of William Samuel Johnson, (14 July 1789); The Notes of William Paterson, (14 July 1789); The Notes of William Paterson, (15-16 July 1789); The Notes of John Adams, 15 July 1789; The Notes of John Adams, (15 or 16 July 1789); The Notes of John Adams, 16 July 1789; The Notes of Paine Wingate, (July 16, 1789); see also http://www.gwu.edu/ $\mathrm{ffcp} / \mathrm{mep} / \mathrm{ffc}-$ toc.html (Last visited July 28,2007 ) (House and senate journals and private notes that do not helpfully discuss the term "alien."). 
term of two years, may be admitted to become a citizen." Here, the foreign-born individuals referred to as "alien" resided in the United States. This act did not use the word "foreigner." 398

\section{F. Notes on the Federal Convention of 1787}

The various notes of the Federal Convention of 1787 exclusively used the broad term "foreigner" in debating foreign affairs, diversity and Supreme Court jurisdiction, etc., 399 and even in debates related to naturalization. ${ }^{400}$

The sole use of "alien" occurred in Madison's notes on August 9, 1787. A motion was made to change the citizenship requirement for Senators from 4 to fourteen years. Oliver Ellsworth opposed this motion because it could discourage, he said, "meritorious aliens" from "emigrating" to the United States. ${ }^{401}$ Again, there is the possibility that the terms were used interchangeably at times. Like Candidus's uses in The Anti-Federalist Papers, Madison's/Ellsworth's use of "alien" here is ambiguous, and therefore not helpful in determining a difference between the terms.

What is helpful is the fact that the debaters (and/or the note-takers) at the 1787 Federal Convention, along with Jefferson and the writers of The Federalist and Anti-Federalist Papers, primarily used the noun "foreigner" when discussing, for example, diversity jurisdiction. ${ }^{402}$ This wide, exclusive use shows that

398. Note that An Act Imposing Duties on Tonnage, enacted during the first session on July 20 , 1789 (but later repealed) used the phrase "subjects of foreign powers."

399. Notes of Rufus King in the Federal Convention of 1787, (June 8, 9, August 8, 1787) available online at http://www.yale.edu/lawweb/avalon/const/king.htm; THE DEBATES IN THE FEDERAL CONVENTION OF 1787 , WHICH FRAMED THE CONSTITUTION OF THE UNITED STATES OF AMERICA, REPORTED BY JAMES MADiSON, A DELEGATE FroM THE STATE OF VirGinia, (May 29, June 5, 15, July 14, August 8, 9, 10, 13, 16, 25, 1787) (Gaillard Hund \& James Brown Scott, eds., 1920); Notes of Alexander Hamilton in the Federal Convention of 1787, http:/www.yale.edu/lawweb/avalon/ const/const05.htm; Notes of Major William Pierce (Georgia) in the Federal Convention of 1787, http://www.yale.edu/lawweb/avalon/const/pierce.htm; Notes of William Paterson in the Federal Convention of 1787, (May 29, 1787) http://www.yale.edu/lawweb/avalon/const/patterson.htm; Notes of the Secret Debates of the Federal Convention of 1787, Taken by the Late Hon Robert Yates, Chief Justice of the State of New York, and One of the Delegates from That State to the Said Convention, (June 13, 29, 1787) http://www.yale.edu/lawweb/avalon/const/yates.htm; Papers of Dr. James McHenry on the Federal Convention of 1787, (August 9, 1787) http://www.yale.edu/lawweb/avalon/ const/mchenry.htm. See also THE RECORDS OF THE FEDERAL CONVENTION OF 1787 (Max Farrand, ed.), http://memory.loc.gov/ammem/amlaw/lwfr.html.

400. See, e.g., Notes of Rufus King in the Federal Convention of 1787, (August 8, 1787); THE DEBATES IN THE FEDERAL CONVENTION OF 1787, WHICH FRAMED THE CONSTITUTION OF THE UNITED STATES OF AMERICA, REPORTED BY JAMES MADISON, A DELEGATE FROM THE STATE OF VIRGINIA, (August 8, 1787), supra note 406.

401. Of course, it is unclear whether Ellsworth said "alien" or if Madison simply wrote "alien" in his notes.

402. Yates noted that "[Edmund ] Randolph observed the difficulty in establishing the powers of the judiciary-the object however at present is to establish this principle, to wit, the security of foreigners where treaties are in their favor, and to preserve the harmony of States and that of the citizens thereof. This being once established, it will be the business of a sub-committee to detail it; and 
the relevant writers and debaters thought about this subject in terms of "foreigners," not "aliens," and therefore it makes sense that Ellsworth would later draft the relevant sections of the original judiciary bill using the broad term "forreigner."

\section{G. State Ratification Debates of the Federal Constitution}

What does not make sense is why the House would change "foreigner" to "alien" before enacting the Judiciary Act of 1789. Again, one argument might be that the terms simply have the same meaning, and it was a stylistic decision. But considering the definitions and uses detailed up to this point (and the rare use of "alien" by the very people who enacted the bill) this is not likely. What is more likely is that the change was a compromise, as Madison suggested, that "removed the principal objections to [the judiciary bill]" 403 and allowed the Judiciary Act of 1789 to pass.

On September 17, 1787, the Continental Congress accepted the recommendation of the Constitutional Convention and agreed to distribute the proposed Constitution to the states. Eeach state then elected delegates to a state convention to approve or disapprove the new Constitution. The Constitution would take effect upon ratification by the conventions of nine of the thirteen states.

Like the debates during the Federal Convention, the ratification debates widely and exclusively used "foreigner" and related terms to refer to foreignborn individuals. The noun "alien" on its own does not appear in any of the State ratification debates. ${ }^{404}$ In the debates and the voluminous collections of supplementary materials collected for the twenty plus volumes of The Documentary History of the Ratification of the Constitution, writers and debaters used various terms other than "alien" numerous times: for example, "foreigner," 405

therefore moved to obliterate such parts of the resolve so as only to establish the principle, to wit, that the jurisdiction of the national judiciary shall extend to all cases of national revenue, impeachment of national officers, and questions which involve the national peace or harmony." Notes of the Secret Debates of the Federal Convention of 1787, Taken by the Late Hon Robert Yates, Chief Justice of the State of New York, and One of the Delegates from That State to the Said Convention, (June 13, 1787) http://www.yale.edu/lawweb/avalon/const/yates.htm. (emphases added). Although "torts" are not mentioned here, the connection between "foreigners," "treaties" and "national peace" could relate to the ATS.

403. THE DAILY ADVERTISER, 18 September 1789, in 11 DHFFC 1479, supra note 16.

404. Although, in the Virginia debates Madison did observe that "an alien enemy cannot bring suit at all" regarding diversity jurisdiction. 10 THE DOCUMENTARY HISTORY OF THE RATIFICATION OF THE CONSTITUTION 1414 (John P. Kaminski \& Gaspar Saladino, et al. eds., 1993).

405. See, e.g., the ratification debates for Massachusetts, Connecticut, New Hampshire, New York, Pennsylvania, Maryland, Virginia, North Carolina, and South Carolina http://constitution.org/elliot.htm (in legislature and in convention); 2 THE DOCUMENTARY HISTORY OF tHE RATIFICATION OF THE CONSTItUTION 436, 519 (Merrill Jensen ed., 1978); 3 THE DOCUMENTARY HISTORY OF THE RATIFICATION OF THE CONSTITUTION 400 (Merrill Jensen ed., 1978); 8 THE DOCUMENTARY HISTORY OF THE RATIFICATION OF THE CONSTITUTION 230, 418, 431, 432, 512 (John P. Kaminski \& Gaspar Saladino, et al. eds., 1993); 9 THE DocuMENTARY HISTORY 
"foreign citizen or subject,"406 "foreign citizen and subject,"407 "foreign subject and citizen," 408 "emigrant," 409 "subject of a foreign power," 410 "citizen or subject of foreign states," 411 "subject of foreign powers," 412 "citizens of foreign states," 413 "foreign states, citizens or subjects," "414 "stranger," 415 etc.

The state ratification debaters discussing naturalization, foreign affairs, diversity jurisdiction, etc., articulated their thoughts regarding foreign-born individuals by using "foreigner" and variations of that term (that is, "foreign citizen or subject," "foreign citizen and subject," "foreign subject and citizen," "subject of a foreign power," "citizen or subject of foreign states," "subject of foreign powers," "citizens of foreign states," "foreign states, citizens or subjects"); 416 never "alien."

Without the use of "alien" throughout the ratification debates, a differentiation between the two terms is impossible, but this situation further demonstrates the fact that "foreigner" was the pervasive way the men who would eventually

OF the Ratification of THE CONSTitution passim (John P. Kaminski \& Gaspar Saladino, et al. eds., 1993); 10 THE DOCUMENTARY HISTORY OF THE RATIFICATION OF THE CONSTITUTION passim, supra note 404.

406. See, e.g., 3 THE DOCUMENTARY History OF THE RATIFICATION OF THE CONSTITUTION, supra note 405 , at 242; 10 THE DOCUMENTARY HISTORY OF THE RATIFICATION OF THE CONSTITUTION, supra note 404, at 1406, 1457.

407. See, e.g., 10 THE DOCUMENTARY History OF THE RATIFICATION OF THE CONSTITUTION, supra note 404 , at 1438; 2 THE DOCUMENTARY HISTORY OF THE RATIFICATION OF THE CONSTITUTION, supra note 405 , at 519.

408. See, e.g., 10 THE DOCumENTARY History OF the RATIFICATION OF THE CONSTITUTION, supra note 404 , at 1422 .

409. See, e.g., 9 THE DOCUMENTARY History OF THE RATIFICATION OF THE CONSTITUTION, supra note 405 , at $809 ; 10$ THE DOCUMENTARY HISTORY OF THE RATIFICATION OF THE CONSTITUTION, supra note 404, at 1190 . Emigrant is generally defined as a person who emigrates from his or her native country.

410. See, e.g., 10 THE DOCUMENTARY History OF THE RATIFICATION OF THE CONSTITUTION, supra note 404 , at $1414 ; 3$ THE DOCUMENTARY HISTORY OF THE RATIFICATION OF THE CONSTITUTION, supra note 405 , at 488 .

411. See, e.g., 10 THE DOCUMENTARY HiSTORY OF THE RATIFICATION OF THE CONSTITUTION, supra note 404 , at 1447.

412. See, e.g., 9 THE DocumentaRy History OF THE RATIFICATION OF THE CONSTITUTION, supra note 405 , at 872 .

413. See, e.g., 10 THE DOCUMENTARY HistoRy OF THE RATIFICATION OF THE CONSTITUTION, supra note 404 , at $1447 ; 2$ THE DOCUMENTARY HISTORY OF THE RATIFICATION OF THE CONSTITUTION, supra note 405, at 625.

414. See, e.g., 10 THE DOCUMENTARY History OF the RATIFICATION OF the CONSTitution, supra note 404 , at 1399 .

415. See, e.g., 9 THE DOCUMENTARY HISTORY OF THE RATIFICATION OF THE CONSTITUTION, supra note 405 , at $766 ; 3$ THE DOCUMENTARY HISTORY OF THE RATIFICATION OF THE CONSTITUTION, supra note 405 , at 256.

416. Other common monikers for "foreigners" in general included: "foreign adventurers," "foreign nations," "foreign powers," "foreign states," "foreign invader," "foreign enemies," "foreign countries," and "allies." See generally 8-10 THE DOCUMENTARY HISTORY OF THE RATIFICATION OF THE CONSTITUTION, supra notes 404-06. 
design and enact the Judiciary Act of 1789 thought about the topic. Why did they change "foreigner" to a word they rarely, if ever, used?

Many of the uses of "foreigner" and its variations listed above occur in debates initiated by anti-federalists regarding diversity jurisdiction and the potential for unfair treatment of United States citizens. Recall the House discussions (detailed in Part I) initiated by Representative Livermore regarding section 3 of the judiciary bill: $\mathrm{He}$ and Representative Stone argued that "foreigners" would have an unfair advantage over citizens because, inter alia, of the speed foreign plaintiffs would collect from defendants in Federal Court. ${ }^{417}$ This was a pervasive and well-articulated fear expressed during the state ratification debates. The best examples occur in Virginia's debates. On June 21, 1788, William Grayson complained that:

Citizens or subjects of foreign States may sue citizens of the different States in the Federal Courts. It is extremely impolitic to place foreigners in a better situation than our own citizens. This was never the policy of other nations. It was the policy in England, to put foreigners on a secure footing. ${ }^{418}$

Grayson vehemently continued:

Our own state merchants would be ruined by it, because they cannot recover debts so soon in the state courts as foreign merchants can recover of them in the federal courts. The consequence would be inevitable ruin to commerce. It will induce foreigners to decline becoming citizens. There is no reciprocity in it. 419

Similarly, a widely published letter appeared less than a year earlier:

There is the most strange desire to give foreigners the advantage in legal pursuits over our fellow citizens $[\ldots \ldots]$ Is there a nation in the world in which an American has such a superiority over the natives? Is it not always held, that the utmost a foreigner can expect, is to be upon par with the natives? What foreigner will desire to become a citizen, when by so doing he will lose that extraordinary pre-eminence? One would think it was calculated to make our country swarm with foreigners, instead of emigrants. 420

Besides distinguishing between a "foreigner" and an "emigrant," which is very similar-if not the same-as distinguishing between a "foreigner" and "alien," this writer articulated the fears expressed by countless others during Virginia's ratification debates: for example, "nor will any foreign nation upon earth grant a similar privilege to our citizens over theirs"; 421 "strangers are not

417. 1 ANNALS OF CONG., supra note 16, at 852; GAZETTE OF THE UNITED STATES, September 9, 1789; Stone said: "A citizen can now get his money in three years, with an interest of $5 \mathrm{pr}$. cent. But in these courts, foreigners can get their debts in one year, with an interest of 7 or 8 pr. cent. From the foregoing I conceive, that this system cannot be agreeable to the people." 1 ANNALS OF CoNG., supra note 16 , at 854 .

418. 10 THE DOCUMENTARY HistoRy OF the RATIFICATION OF the CONSTITUTION, supra note 404 , at 1447 .

419. Id.

420. VIRGINIA INDEPENDENT CHRONICLE, 14 November 1787, in 8 THE DOCUMENTARY HISTORY OF THE RATIFICATION OF THE CONSTITUTION, supra note 405, at 157-58.

421. Letter from Richard Henry Lee to Samuel Adams, (April 28, 1788) in 9 THE 
to have privileges in [a] country superior to what [its] own subjects enjoy"; ${ }^{422}$ "Suits of foreigners against states or citizens thereof [must be] eliminated from jurisdiction of federal judiciary"; 423 "I believe you will find that this degrading idea of our courts is truly original, and that nothing similar to it, is to be found in the history of nations"; 424 "How far it might be proper to authorize the subjects of foreign powers to carry the citizens of any state into the federal court, and afterwards by appeal into the Supreme Court, is of questionable propriety"; 425 "Is not this disgraceful?[-] Is this the case in any other country?-Are not men obliged to stand by the laws of the country where the disputes are?-This is an innovation which is utterly unprecedented and unheard of"; 426 "[this] will utterly annihilate your State Courts"; 427 "ultimately destroy the State Judiciaries, and ... the legislation of the State Governments." ${ }^{428}$

The arguments that "foreigners" would not choose to emigrate, that commerce and the State judiciaries and legislatures would be destroyed, that United States citizens would basically be treated unfairly (unlike foreign citizens in and outside their own countries) -all these valid arguments continued during the House discussions regarding section 3 of the judiciary bill. Considering the length of those reported debates, the error regarding alienage jurisdiction in section 11 of the judiciary bill, the deletion of foreign states as parties, etc., the unfortunately unreported House debates regarding sections 9-13 must have been extensive. Representatives not only wanted to limit interference with international matters, ${ }^{429}$ they wanted to create a fair system for United States citizens. One way to alleviate this intense anti-federalist pushback would be to narrow the class of "foreigners."

By limiting, for example, diversity jurisdiction to where an "alien is a party," 430 not where "a foreigner . . . is a party," 431 this would protect a class of foreign-born individuals who, like citizens-as repeatedly defined and used in

DOCUMENTARY HISTORY OF THE RATIFICATION OF THE CONSTITUTION, supra note 405, at 766 .

422. Id.

423. The Society of Western Gentlemen Revise the Constitution, VIRGINIA INDEPENDENT Chronicle, 30 April, 7 May, in 9 THE Documentary History of tHe RATIFICATION OF THE CONSTITUTION, supra note 413 , at 771.

424. Brutus' answer to Cassius, VIRGINIA INDEPENDENT CHRONICLE, 14 May, in 9 THE DOCUMENTARY HISTORY OF THE RATIFICATION OF THE CONSTITUTION, supra note 405 , at 802.

425. James Monroe: Some Observations on the Constitution, c. May 25, in 9 THE DOCUMENTARY HISTORY OF THE RATIFICATION OF THE CONSTITUTION, supra note 405, at 872.

426. Virginia Ratification Debates, 19 June, George Mason debating with James Madison, in 10 THE DOCUMENTARY HistoRY OF THE RATIFICATION OF THE CONSTITUTION, supra note 404, at 1406.

427. Id. at 1407 .

428. Id.

429. See supra Part III.B.4

430. The Judiciary Act of $1789, \S 11$.

431. Senate's Printed Draft, $\S 11$. 
the eighteenth century-deserved the sovereign's protection. ${ }^{432}$ Remember, Ambassadors et al. were covered in other sections of the Judiciary Act of 1789 and the Constitution. And although "alien" would not impose the full force of the constitutional directive-"foreign . . . Citizens or Subjects"-it would bring diversity jurisdiction in line with, for example, English practices, and put "emigrants" or "aliens" in a better position than the broad class of "foreigners" (therefore, inter alia, encouraging emigration and creating a fair system for citizens), and therefore placate the anti-federalists into approving the judiciary bill.

Of course, the "alien" designation concerning diversity and Supreme Court jurisdiction is an illusion, because the Constitution goes farther. The argument could always be made that "foreign . . . Citizens or Subjects" in general deserved their day in Federal court, because the Constitution-the supreme law of the land-says so. However, the Constitution is silent regarding the ATS, and therefore the plain meaning of it must stand on its own. By limiting the ATS to "aliens," not every injured foreigner throughout the world could bring a tort claim based on the law of nations, only those deserving protection"aliens"-could. This would likely mitigate the intense anti-federalist pushback described above.

VI. CONGRESS LIMITED THE ATS TO “ALIENS" ONLY

The myriad definitions, relevant writings, acts, debates and available opinions indicate that the Senate's original draft of the Judiciary Act of 1789 intended to make the ATS available to all persons born outside (and not a citizen of) the United States (that is, "forreigners"), but Congress narrowed the scope in the Judiciary Act of 1789 and in later codifications, making the ATS only available to plaintiffs who are "aliens" (that is, foreign-born residents of the several States). ${ }^{433}$

Shortly after the Judiciary Act of 1789 was enacted, the House delegated to the Attorney General the task of reporting on the judiciary system and to propose a plan of revisions. ${ }^{434}$ Among the revisions he proposed was to eliminate

432. Blackstone, among others, specified that aliens, not foreigners, "fall under the denomination of the people" who deserve rights within the realm. 1 COMMENTARIES, supra note 158 , at *35184. In England, denizens were above aliens in that they could own land, but below full subjects in that they could not inherit, or hold office. Id. Thus, while they were technically "subjects" in 1789 in that they owed obedience to the King, their status was unlike (and inferior to) every natural-born British subject. Id.; see also KETTNER, supra note 162, at 5 (tracing degrees of subjectship under English law).

433. Note that Ellsworth clearly understood that the U.S. lacked "jurisdiction over transactions in foreign countries." Casto, supra note 3, at 485-86 n.97 (quoting a letter from Ellsworth to Jonathan Trumbull).

434. See supra note 182. 
the references to "alien" and adopt the constitutional language of "foreign . . . Citizens or Subjects." 435 But the references to "alien" the Attorney General indicated to Congress included all uses of that term except the "alien" in the line that later became known as the ATS. ${ }^{436}$ This further indicates that the ATS was not to be used by all "foreign . . Citizens or Subjects"-like, for example, diversity jurisdiction — but only by a certain subset of "foreigners"- "aliens." 437

The 1911 codification of the Judiciary Act finally changed the Judiciary Act of 1789 to conform to the Constitution. ${ }^{438}$ For example, the diversity line in the Act was changed from: The courts shall have original jurisdiction where "the United States are plaintiffs, or petitioners; or an alien is a party, or the suit is between a citizen of the State where the suit is brought, and a citizen of another State," to "The district courts shall have original jurisdiction ... [of] all suits of a civil nature ... [involving] citizens of different States, or . . citizens of a State and foreign . . citizens, or subjects." 439 As the Attorney General found over a century before, the term "alien" used in this context was inappropriate. ${ }^{440}$

But Congress did not similarly change the ATS line in 1911: "The district courts shall have jurisdiction ... [of] all suits brought by any alien for a tort only, in violation of the law of nations, or of a treaty of the United States." 441

The House changed diversity jurisdiction to clearly include any foreignerbringing it in line with the way the state ratification debaters and drafters discussed and thought about it, and with the Constitution - but kept the ATS line virtually the same to include only "aliens." Like the change from "foreigner" to "alien" in the Judiciary Act of 1789, this change was not happenstance. The current codification, effected in 1948, reflected a similar Congressional intent. ${ }^{442}$ The ATS, 28 U.S.C. section 1350, barely changed from its 1911 codification: "The district courts shall have original jurisdiction of any civil action by an alien for a tort only, committed in violation of the law of nations ...."

The diversity statute also barely changed in 1911, but more recent, additional language indicates a further Congressional understanding of "alien":

435. 37 American State Papers Miscellaneous 26, 29.

436. See id. at 21-36.

437. For example, the Attorney General recommended "alien" in the line regarding diversity jurisdiction changed to track the Constitution-a move that would have cleared up confusion the Supreme Court eventually had to rectify. Unfortunately, though, the Congress did not address the problem until the late nineteenth century.

438. Act of Mar. 3, 1911, ch. 231, § 24, 36 Stat. 1093. \17.

439. Id. at $\uparrow 1$.

440. No Congressional notes or discussions regarding the change from "alien" could be located.

441. § 24, 36 Stat. 1093. ๆ17; see also Rev. State. § 563 (1874) (this late nineteenth century codification of the ATS states: "The District Court shall have jurisdiction as follows: . . . Of all suits brought by an alien for a tort 'only' in violation of the law of nations, or a treaty of the United States.").

442. 28 U.S.C. $\S 1350$. 
a) The district courts shall have original jurisdiction of all civil actions . . . between-

(1) citizens of different States;

(2) citizens of a State and citizens or subjects of a foreign state;

(3) citizens of different States and in which citizens or subjects of a foreign state are additional parties; and

...

For the purposes of this section ... an alien admitted to the United States for permanent residence shall be deemed a citizen of the State in which such alien is domiciled. 443

Here, the "alien" clarification indicates that "aliens" are different from "citizens or subjects of a foreign state"; that is, Congress is not generally classifying an "alien" as a "foreigner" here. The use of "alien" refers only to an individual domiciled in the United States.

At the same time as adding this language, the House again retained the use of "alien" in section 1350, the ATS. This is further evidence that "alien" in the ATS refers to a foreign-born individual "domiciled" here in the United Statesthe same as a "citizen"-in that the "alier" is not an individual residing extraterritorially. ${ }^{444}$

One problem with the ATS has always been the question of why would the First Federal Congress pass-and subsequent Congresses-perpetuate such an open-ended law that only benefits individuals with utterly no connection to the United States. ${ }^{445}$ The answer is, they did not.

The narrow definition of "alien" today and in 1789 shows that the ATS was designed to protect foreign-born individuals who deserve protection due to their relation to the sovereign as "aliens." 446 The narrower definition would encourage "foreigners" to emigrate, or to trade here, so they could be "aliens" and have standing in regards to torts in violation of the law of nations or treaties of the United States. ${ }^{447}$ The narrower definition would make more sense, because the United States has never claimed to have this type of extraterritorial jurisdiction, and leaving the ATS open-ended continually invites this improper jurisdiction. By limiting the ATS to "aliens," who to remain as such must reside, temporarily

443. 28 U.S.C. $\S 1332$.

444. Recall Blackstone: The alien was only "bounden" to the sovereign during the alien's residence in the sovereign's territory. I COMMENTARIES, supra note 158 , at $* 358$. Once the alien leaves "the king's dominion and protection," Blackstone stopped referring to the "alien" as such, then used the word "stranger": hence the "stranger transfers himself from the kingdom to another," losing his allegiance. Id. That is, once the individual is out of the king's protection, he is no longer an "alien," but a "stranger" or "foreigner." Id.

445. See, e.g., Roe I v. Bridgestone, 2009 WL 553901 at *14 (S.D. Ind., March 4, 2009) (stating that "the [ATS] does not mean that the court must open its doors to address the plights of thousands of people who will never come anywhere near the United States or this court. Not all the world's problems can be fixed in the courts of [the] United States.").

446. See Lee, supra note 5, at 907 .

447. Id. at 838,840 . 
or otherwise, in the United States, properly limits the scope of the ATS. ${ }^{448}$

In fact, when Congress enacted the Torture Victim Protection Act of 1991 ("TVPA"), ${ }^{449}$ it "expressly ratified" the Second Circuit's ATS holding in Filartiga v. Pena-Irala, where the plaintiffs were foreign-born residents of the United States. ${ }^{450}$ In doing so, Congress also intended to strengthen the ATS by making it available to U.S. citizens as well as aliens. ${ }^{451}$ In discussing this, the TVPA drafters explicitly stated that the new act will protect U.S. citizens and-like the ATS-it will protect aliens "living in this country." 452 This statement came very early in the TVPA discussions, but on January 3, 1991, as the act was about to be enacted, co-sponsor Senator Arlen Specter told Congress and the President: "This [TVPA] would extend protection to U.S. Citizens while retaining the [ATS's] protection of aliens." ${ }^{453}$ Following Senator Specter, co-sponsor Senator Edward Kennedy made Congress's understanding of the ATS's protection of aliens clear: "This [TVPA] is a modest step. There are reasonable limits to what we can achieve, in part because our laws require that both the [plaintiff] and the [defendant] must be present in the United States for the matter to be considered."454 Thus, Congress's interpretation of the ATS, as used effectively for the first time in Filartiga, was that the plaintiff must be an "alien"; must reside in the United States.

\section{VII. \\ CONCLUSION}

Because of the narrower definition of "alien" understood in the eighteenth century, and if for the purposes of the TVPA, 28 U.S.C. $\S 1332$, and 8 U.S.C.S. $\S \S 1101(a)(3)$ and (15) an "alien" is considered by Congress a resident of the United States, it follows that an "alien" in the ATS is also considered as such. Consequently, individuals who deserve protection by the sovereign are protected, emigration, international trade and even tourism are encouraged, citizens are not treated unequally, the State courts and legislatures are preserved, as is the separation of powers, and extraterritorial jurisdiction is not breached. ${ }^{455}$

448. See id. at 838-39 for a similar conclusion for reasons based on the "Safe-Conduct theory."

449. 28 U.S.C. $\S 1350$, n.2.

450. 630 F.2d 876 (1980); See Wiwa v. Royal Dutch Petroleum Co., 226 F.2d 88, 104 (2d Cir. 2000).

451. Hearing and Markup re: 100 HR 1417, Committee on Foreign Affairs, March 23, Apr. 20, and June 7,1988 at 1.

452. Id.

453. 137 CONG. REC. $\$ 1378$.

454. Id. (emphasis added).

455. Recall that Blackstone points out that certain "foreigners," who would today be referred to as "aliens," were "intitled [sic] to safe-conduct and security throughout the kingdom" only. 4 COMMENTARIES, supra note 160, at *70 (emphasis added). 